\title{
Genomic diversity and evolution, diagnosis, prevention, and therapeutics of the pandemic COVID-19 disease
}

\author{
M. Nazmul Hoque ${ }^{1,2}$, Abed Chaudhury ${ }^{3}$, Md. Abdul Mannan Akanda ${ }^{4}$, M. Anwar Hossain ${ }^{5}$, Md Tofazzal Islam $^{\text {Corresp. }}$ \\ 6 \\ 1 Department of Gynecology, Obstetrics and Reproductive Health, Bangabandhu Sheikh Mujibur Rahman Agricultural University (BSMRAU), Gazipur 1706, \\ Bangladesh \\ 2 Department of Microbiology, University of Dhaka, Dhaka, Bangladesh \\ 3 Charles Sturt University, Orange, NSW, Australia \\ 4 Department of Plant Pathology, Bangabandhu Sheikh Mujibur Rahman Agricultural University (BSMRAU), Gazipur 1706, Bangladesh \\ 5 Jashore University of Science and Technology, Jashore 7408, Bangladesh, Jashore, Bangladesh \\ 6 Institute of Biotechnology and Genetic Engineering (IBGE), Bangabandhu Sheikh Mujibur Rahman Agricultural University (BSMRAU), Gazipur 1706, \\ Bangladesh \\ Corresponding Author: Md Tofazzal Islam \\ Email address: tofazzalislam@yahoo.com
}

The coronavirus disease 19 (COVID-19) is a highly transmittable and pathogenic viral infection caused by a novel evolutionarily divergent RNA virus, the severe acute respiratory syndrome coronavirus 2 (SARS-CoV-2). The virus first emerged in Wuhan, China in December 2019, and subsequently spreaded around the world. Genomic analyses revealed that this zoonotic virus may be evolved naturally but not a purposefully manipulated laboratory construct. However, currently available data are not sufficient to precisely conclude the origin of this fearsome virus. Comprehensive annotations of the whole-genomes revealed hundreds of nucleotides, and amino acids mutations, substitutions and/or deletions at different positions of the ever changing SARS-CoV-2 genome. The spike (S) glycoprotein of SARS-CoV-2 possesses a functional polybasic (furin) cleavage site at the S1-S2 boundary through the insertion of 12 nucleotides. It leads to the predicted acquisition of 3-O-linked glycan around the cleavage site. Although real-time RTPCR methods targeting specific gene(s) have widely been used to diagnose the COVID-19 patients, however, recently developed more convenient, cheap, rapid, and specific diagnostic tools targeting antigens or CRISPR-Cas-mediated method or a newly developed plug and play method should be available for the resource-poor developing countries. A large number of candidate drugs, vaccines and therapies have shown great promise in early trials, however, these candidates of preventive or therapeutic agents have to pass a long path of trials before being released for the practical application against COVID-19. This review updates current knowledge on origin, genomic evolution, development of the diagnostic tools, and the preventive or therapeutic remedies of the COVID-19. We also 
discussed the future scopes for research, effective management, and surveillance of the newly emerged COVID-19 disease. 
1 Genomic diversity and evolution, diagnosis, prevention, and therapeutics of the pandemic

2

3

4 Running Title: Genomic analysis, diagnosis, and management of COVID-19

5

6 M. Nazmul Hoque ${ }^{1,2}$, Abed Chaudhury ${ }^{3}$, Md. Abdul Mannan Akanda ${ }^{4}$, M. Anwar Hossain ${ }^{1,5}$, Md

7 Tofazzal Islam $6^{*}$

$8{ }^{1}$ Department of Microbiology, University of Dhaka, Dhaka 1000, Bangladesh

9 2Department of Gynecology, Obstetrics and Reproductive Health, Bangabandhu Sheikh Mujibur

10 Rahman Agricultural University (BSMRAU), Gazipur-1706, Bangladesh

$11{ }^{3}$ Charles Sturt University Campus, Orange, NSW, Australia

12

${ }^{4}$ Department of Plant Pathology, BSMRAU, Gazipur-1706, Bangladesh

${ }^{5}$ Jashore University of Science and Technology, Jashore 7408, Bangladesh

${ }^{6}$ Institute of Biotechnology and Genetic Engineering (IBGE), BSMRAU, Gazipur-1706, Bangladesh

*Corresponding authors: Md Tofazzal Islam, e-mail: tofazzalislam@yahoo.com 


\section{Abstract}

26

The coronavirus disease 19 (COVID-19) is a highly transmittable and pathogenic viral infection caused by a novel evolutionarily divergent RNA virus, the severe acute respiratory syndrome coronavirus 2 (SARS-CoV-2). The virus first emerged in Wuhan, China in December 2019, and subsequently spreaded around the world. Genomic analyses revealed that this zoonotic virus may be evolved naturally but not a purposefully manipulated laboratory construct. However, currently available data are not sufficient to precisely conclude the origin of this fearsome virus. Comprehensive annotations of the whole-genomes revealed hundreds of nucleotides, and amino acids mutations, substitutions and/or deletions at different positions of the ever changing SARS$\mathrm{CoV}-2$ genome. The spike (S) glycoprotein of SARS-CoV-2 possesses a functional polybasic (furin) cleavage site at the S1-S2 boundary through the insertion of 12 nucleotides. It leads to the predicted acquisition of 3-O-linked glycan around the cleavage site. Although real-time RT-PCR methods targeting specific gene(s) have widely been used to diagnose the COVID-19 patients, however, recently developed more convenient, cheap, rapid, and specific diagnostic tools targeting antigens or CRISPR-Cas-mediated method or a newly developed plug and play method should be available for the resource-poor developing countries. A large number of candidate drugs, vaccines and therapies have shown great promise in early trials, however, these candidates of preventive or therapeutic agents have to pass a long path of trials before being released for the practical application against COVID-19. This review updates current knowledge on origin, genomic evolution, development of the diagnostic tools, and the preventive or therapeutic remedies of the COVID-19. We also discussed the future scopes for research, effective management, and surveillance of the newly emerged COVID-19 disease. 
49 Key words: SARS-CoV-2, Genetic Diversity, Genome Evolution, Diagnostics, Therapeutics, 50 Vaccines

51

52

53

54

55

56

57

\section{Introduction}

Emergence and reemergence of various pathogens pose global challenges for public health and human food security (Islam et al., 2016; Gao, 2018). The novel coronavirus, SARS-CoV-2 has emerged as one of the deadliest viral human pathogens in last one hundred years after the Spanish Flu in 1918 (Reid et al. 1999). In late December 2019, the World Health Organization was notified of a cluster of cases of pneumonia disease of unknown etiology in Wuhan of Hubei Province of China. Soon afterwards, the researchers assumed that the culprit pathogen is a new coronavirus, which causes a severe acute respiratory syndrome in the infected patients. Based on phylogenomics and transmission electron microscopic analyses, Zhou et al. (2020a) first confirmed the pathogen as a novel coronavirus and named it as $2019-\mathrm{nCoV}$. Later, this new virus was renamed as SARS-CoV-2 and the disease caused by this virus was termed as COVID-19 by the Coronavirus Study Group of the International Committee on Taxonomy of Viruses (ICTV). The SARS-CoV-2 is the third devastating coronavirus $(\mathrm{CoV})$ that infects human. Earlier, two similar zoonotic coronaviruses that emerged as epidemics to cause human infections were severe acute respiratory syndrome (SARS-CoV) in 2003 (Zaki et al., 2012; Almofti et al., 2018), and the Middle East respiratory syndrome (MERS-CoV) in 2012 (Badawi et al., 2016; Pallesen et al., 2017; Ul Qamar et al., 2019). Surprisingly, the COVID-19 disease rapidly spread to almost whole world within a few months and poses a serious threat to human health globally. Considering the contagious behavior and fatality of the COVID-19, WHO declared it as a Public Health Emergency of International Concern (WHO, 2020). As of June 25, 2020, the COVID-19 has spread to 216 countries or territories, infecting at least 91,62,375 people of which around 4,73,087 people died 
73 globally. The rapidly spreading person-to-person transmission of SARS-CoV-2 has been

74 confirmed by detecting the virus in a wide range of samples including bronchoalveolar-lavage

75 (Zhu et al., 2020; Nishiura et al., 2020), sputum (Lin et al., 2020), saliva (To et al., 2020), throat

76 (Bastola et al., 2020) and nasopharyngeal swabs (To et al., 2020).

The SARS-CoV-2 belongs to the genus Betacoronavirus under the family Coronaviridae,

is a positive-sense single-stranded RNA (+ssRNA) virus. The Coronaviridae is one of the largest viral families. Viruses under this family have potential ability to infect and subsequently cause diseases to a large number of mammals, birds, and humans (Ahmed et al., 2020; Hemida and Abduallah, 2020). The coronaviruses manifest a wide variety of clinical sign and symptoms, which include respiratory, nervous, enteric, and systemic health problems (Hemida and Abduallah, 2020; Huang et al., 2020). Within weeks of the first outbreak of COVID-19 disease in Wuhan, the complete genome sequence of this novel virus was published (Zhou et al., 2020a). Approximately, 30 kilobase sized genome of the novel SARS-CoV-2 encodes several smaller open reading frames (ORFs) (Rota et al., 2003; Freundt et al., 2010; Cotton et al., 2013). These ORFs encode for different proteins for example the replicase polyprotein, the spike (S) glycoprotein, envelope (E), membrane $(\mathrm{M})$, nucleocapsid $(\mathrm{N})$ proteins, accessory proteins, and other non-structural proteins (nsp) (Ahmed et al., 2020; Islam et al., 2020; Phan, 2020; Walls et al., 2020). The genome of SARS-CoV-2 coupled with regions of genomic instability (Abdelmageed et al., 2020; Rahman et al., 2020), which encodes for multiple structural and non-structural proteins (Ahmed et al., 2020; Rahman et al., 2020) with many unique features. These features make these proteins prone to frequent coding changes, thus generating new strains in a short period of time (Hemida and Abduallah, 2020; Islam et al., 2020). Rapid mutational frequencies are associated with the poor proofreading efficiency of the viral RNA polymerase, and the likelihood of recombination between 
96

97

different members of this family (Jackwood et al., 2012; Phan, 2020). Relatively faster spread and varying levels of fatality of SARS-CoV-2 in different countries raises an intriguing question whether the evolution of this virus is driven by mutations. To address these question, several recent studies reported that substitution and/or deletion of nucleotides and amino acids (aa) at the entire genome of SARS-CoV-2 are the important mechanisms for virus evolution in nature (Huang et al., 2020; Islam et al., 2020; Phan, 2020; Yin, 2020). Due to the practice of open science, the research progress on SARS-CoV-2 is the fastest moving subject in the human history. In about six months, thousands of reports and data on genomics, origin, genome evolution, molecular diagnosis and vaccine and/or therapeutics of the SARS-CoV-2 have been published (Clover B, 2020; Geo-Vax, 2020; Islam et al., 2020; Phan, 2020; Rahman et al., 2020; Shereen et al., 2020; Shanmugaraj et al., 2020; Walls et al., 2020; Zhang et al., 2020a).

Genomic analyses of the SARS-CoV-2 virus revealed that evolution of this virus is mainly driven by genetic drift and founder events (Chiara et al., 2020; Huang et al., 2020; Islam et al., 2020; Yin, 2020). Nevertheless, many researchers predicted a possible adaptation at the nucleotide, aa, and structural heterogeneity in the viral proteins, especially the spike (S) protein (ArmijosJaramillo et al., 2020; Islam et al., 2020; Sardar et al., 2020). Recently, Shen et al. (2020) reported even an intra-host viral evolution during infection which might be related to its virulence, transmissibility, and/or evolution of virus response against the host immune system. To carry out its function, SARS-CoV-2 S protein binds to its receptor human angiotensin converting enzyme 2 (hACE2) through its receptor-binding domain (RBD), and is proteolytically activated by human proteases (Shang et al., 2020a). The efficient cell entry of the SARS-CoV-2 is mediated by the high hACE2 binding affinity of the RBD, furin preactivation of the spike, and hidden RBD in the spike while evading immune surveillance (Shang et al., 2020a). The virulence mechanisms of the 
119 SARS-CoV-2 are not fully understood (Khan et al., 2020a; Zhou et al., 2020b). It has been known 120 that after cellular entry to the susceptible host, the SARS-CoV-2 manifests several clinical 121 syndromes including pneumonia, fever, cough, shortness of breath, muscle pain (myalgias), 122 fatigue, confusion, headache, sore throat, acute respiratory distress, and eventually multiorgan 123 failure (Jiang et al., 2020). Therefore, unravelling the cellular factors involved in entry of SARS124 CoV-2 might give further insights into the transmission of the virus, and reveals the therapeutic 125 targets (Hoffmann et al., 2020a; Hemida and Abduallah, 2020). However, the clinical sign and 126 symptoms of SARS-CoV-2 in confirmed patients were highly variable. Therefore, the 127 confirmatory diagnosis of COVID-19 is made with the aid of real-time reverse transcriptionpolymerase chain reaction (RT-PCR), computed tomography (CT)-scan, immune identification 129 technology (Point-of-care Testing, POCT) of IgM/IgG, CRISPR-Cas or blood culture (Ai et al., 130 2020; Corman et al., 2020; Hindson, 2020; Kellner et al., 2020; Li et al., 2020a; Wang et al., 131 2020a). Although RT-PCR is considered as gold standard, the development of new, low cost, 132 convenient, rapid and specific diagnostic protocols are needed for monitoring, surveillance and management of this pandemic disease.

No effective therapeutic drugs or vaccines are yet to be discovered for the treatment of SARS-CoV-2 patients. Currently, some supportive cares are given to the patients such as oxygen therapy, antiviral combination with antibiotic, convalescent plasma therapy, antifungal treatment, and extra-corporeal membrane oxygenation (ECMO) (Chen et al., 2020; Holshue et al., 2020). Researchers across the globe are searching to find an antiviral drug useful in treating the infection of SARS-CoV-2. They evaluated several drugs or therapies namely, penciclovir, ribavirin, nitazoxanide, remdesivir (GS-5734), nafamostat, favipiravir (T-750) or Avigan, avermectins, dexamethasone, EIDD-2801, hydroxychloroquine, chloroquine, and convalescent plasma (CP) 
142 therapy against the infection of SARS-CoV-2 (Duan et al., 2020; Liu et al., 2020; Martinez, 2020;

143 Wang et al., 2020b). The high mutation rate of the RBD leading to the faster evolution and high

144 genomic disparity of this virus may help the new strains of this RNA virus to get away 145 neutralization mechanism by RBD-targeting antibodies (Rahman et al., 2020). Therefore, non146 RBD functional regions of the S glycoprotein could efficiently be selected for developing and 147 devising effective therapeutic and prophylactic interventions against the infection by SARS-CoV148 2. Several monoclonal antibodies (mAbs) with potent neutralizing activity targeting the $\mathrm{N}$-terminal 149 domain (NTD) of the S protein of SARS-CoV-2 has already been reported (Shang et al., 2020b; 150 Wang et al., 2019; Zhou et al., 2019). In addition to S protein, two smaller proteins, E and M might 151 also participate in the viral assembly of a coronavirus, and can mimic both cell-mediated and 152 humoral immunity against SARS-CoV-2 (Shi et al., 2006; Schoeman and Fielding, 2019; Shang 153 et al., 2020b). At least 90 vaccine candidates are now under trials for evaluating their efficacy and 154 safety, and some of them are advanced to human trials (Corey et al. 2020).

155 Due to the practices of open science and open data sharing approaches, the literature generating through research on SARS-CoV-2 is simply explosive. The specific features of emerging pandemics, epidemiology, clinical characteristics, pathophysiology, diagnosis, treatment, ongoing clinical trials and prevention of the SARS-CoV-2 have been discussed in several reviews (Guo et al., 2020; Tay et al., 2020; Tu et al., 2020; Valencia, 2020; Udugama et al. 2020). However, no comprehensive review on the genomic diversity and evolution, diagnosis, prevention, and therapeutics of the SARS-CoV-2 has been published. Therefore, this report aims to review our current understanding on origin, genomic evolution, clinical and molecular diagnosis as well as prevention and control of the SARS-CoV-2 infection. Furthermore, this review also 
164 provides valuable information for further research and promotes responses of the relevant national

165 and international authority to tackle this pandemic disease.

166

167 Review methodology and rationale

From the very beginning of the first outbreak of SARS-CoV-2 in December, 2019 in

Wuhan Province of China, thousands of reports and data on genomics, origin, genome evolution, molecular diagnosis and vaccine and/or therapeutics of SARS-CoV-2 have been published. To prepare this review, we conducted a literature survey on the SARS-COV-2 in last six months. First, we focused the introduction section on the historical background of coronaviruses, genome composition and diversity, and progresses in the preventive measures against the SARS-CoV-2. We then searched the most up-to-date literature from PubMed central, Google Scholar, ResearchGate, bioRxiv, Preprints archives, China National Center for Bioinformation 2019 Novel Coronavirus Resource (2019nCoVR) and World Health Organization COVID-19 blog on the genome composition and diversity, genome-evolution and genome-wide mutations in SARS-CoVsome important genome-wide mutations either at nucleotide or aa level that associated with the ever-changing phenomena of the virus irrespective of the geography and ethnicity. We also summarized the current acceptable theories on the emergence and evolution of SARS-CoV-2. Finally, we highlighted the progress to date in the control of SARS-CoV-2. Historically, the SARSCoV-2 is the first pandemic affecting the entire globe with 216 countries or territories. diagnosis, prevention, and therapeutics of the SARS-CoV-2 has been published. This review will 
187 be useful for academicians, researchers and policymakers across the globe to better understand

188 COVID-19, which will ultimately pave them a way for prevention and control of this pandemic 189 disease.

190

191

192

193

194

195

196

197

198

199

200

201

202

203

204

205

206

207

208

209

\section{Genomic composition of the SARS-CoV-2}

The positively-sensed single-stranded RNA SARS-CoV-2 virus (Ahmed et al., 2020) has a genome size of approximately $30 \mathrm{~kb}$ (range: $29.8 \mathrm{~kb}$ to $29.9 \mathrm{~kb}$ ) (Khailany et al., 2020). It shares only about $80 \%$ sequence identity to the previously reported human coronaviruses (Wu et al., 2020a). The RNA molecule of the virus is surrounded by various proteins including S, M, E, and $\mathrm{N}$ (Ahmed et al., 2020). The genome of SARS-CoV-2 encodes for several smaller ORFs located in both in 5'-UTR and 3'-UTR regions of the genome (Fig. 1 A-C) that are assumed to express eight new proteins termed as accessory proteins (Rota et al., 2003; Freundt et al., 2010). The 5'UTR and 3'-UTR of the CoVs play vital roles in intra- and intermolecular interactions. They are functionally significant for RNA-RNA interactions, and for binding of viral and cellular proteins (Yang and Leibowitz, 2015). The first ORF at the 5' end is Pblab, which encodes for several nonstructural proteins with the sizes of $29,844 \mathrm{bp}(7,096$ aa), 29,751 bp (7,073 aa) and 30,119 bp (7,078 aa) in SARS-CoV-2, SARS-CoV, and MERS-CoV, respectively. Differences at positions of 1,273 aa, 21,493 aa, and 1,270 aa in SARS-CoV-2, SARS-CoV, and MERS-CoV, respectively have been reported (Mousavizadeh and Ghasemi, 2020). Genetically, the SARS-CoV-2 is very less similar to SARS-CoV (about 79\%) or MERS-CoV (about 50\%) (Mousavizadeh and Ghasemi, 2020). The genomic position of the $\mathrm{E}, \mathrm{M}$, and $\mathrm{N}$ proteins among betacoronaviruses are different as depicted in Fig. 1. The accessory proteins are labelled as ORFs 1a and 1b (polyprotein), 3a, 3b, 6, 7a, 7b, 8a, 8b, $9 \mathrm{~b}$ and 10 (Fig. 1 A-C). The size of these ORFs range from 39 to 274 aa (Marra 
210 et al., 2003; Freundt et al., 2010). These ORFs also encode for the replicase polyprotein, structural

211 proteins, and other non-structural proteins (nsp) (Ahmed et al., 2020; Walls et al., 2020; Phan,

212 2020). The orflab is the largest gene in SARS-CoV-2, which encodes the polyprotein (pplab) and

21315 nsps. The orfla gene encodes for ppla protein which also contains 10 nsps (Shereen et al.,

214 2020). Noticeable differences between SARS-CoV and SARS-CoV-2 genomes such as absence of

215 8a protein and fluctuation in the number of aa in $8 \mathrm{~b}$ and $3 \mathrm{c}$ protein in SARS-CoV-2 have been 216 reported in several studies (Shereen et al., 2020; Wu et al., 2020a).

217 The CoVs use their S glycoprotein, a main target for antibody neutralization, to bind their 218 receptor, mediate membrane fusion and entry into the host cell. Each monomer of homotrimeric S 219 protein is about $180 \mathrm{kDa}$ in size, which contains S1 and S2 subunits for mediating attachment and 220 membrane fusion, respectively. The $\mathrm{N}$ - and $\mathrm{C}$ - terminal portions of S1 comprises two major 221 domains S1 fold as two independent domains, the RBD and N-terminal domain (NTD) (Song et 222 al., 2018; Ou et al., 2020; Rahman et al., 2020). While RBD of mouse hepatitis virus (MHV) is 223 located at the NTD (Kubo et al., 1994), most of other CoVs, including SARS-CoV and MERS224 CoV use C-domain to bind their receptors (Li et al., 2005; Lu et al., 2013; Ou et al., 2020). During 225 the pathogenesis, the trimeric S protein is cleaved into S1 and S2 subunits, and the RBD of the S1 subunit directly binds to the peptidase domain (PD) of ACE2 while the S2 carried out membrane fusion activity (Yan et al., 2020). Structural and biochemical studies revealed that the SARS-CoV2 has an RBD which binds with high affinity to ACE2 from humans, ferrets, cats and other species with high receptor homology (Andersen et al., 2020; Wan et al., 2020; Walls et al., 2020; Wrapp et al., 2020; Zhou et al., 2020a). Therefore, the RBD of SARS-CoV-2 is a particularly snug fit, and 10-20 times more likely to bind ACE2 than SARS-CoV (Wrapp et al., 2020). Due to these novel genomic features (i) SARS-CoV-2 arises to be optimized for binding to the human ACE2 
233 receptor; and (ii) the S protein of SARS-CoV-2 possesses a functional polybasic (furin) cleavage 234 site at the S1-S2 boundary by way of the insertion of 12 nucleotides (Walls et al., 2020), which 235 additionally led to the assumed acquisition of 3-O-linked glycans around the site. Moreover, this 236 polybasic cleavage site "RRAR" is unique in SARS-CoV-2, rendering by its unique insert of 237 "PRRA", and might have evolved from other human betacoronaviruses, including HKU1 (lineage 238 A), and MERS-CoV (Andersen et al., 2020). Proteolytic cleavage sites of the S protein can 239 determine whether the virus is evolved from a cross species, e.g. from bats to humans (Andersen 240 et al., 2020). However, the functional furin cleavage site is absent in related 'lineage B' 241 betacoronaviruses like the bat coronavirus strain, RaTG13 (Andersen et al., 2020; Coutard et al., 242 2020). Functional polybasic cleavage at the $\mathrm{S} 1 / \mathrm{S} 2$ site is essential for spike-driven viral entry into 243 lung cells (Hoffmann et al., 2020b). Lau et al. (2020) suggested that the unique cleavage PRRA 244 motif under strong selective pressure could promote SARS-CoV-2 infection in humans. Moreover, 245 the S protein of SARS-CoV-2 encodes $22 \mathrm{~N}$-linked glycan sequons per protomer, which play a 246 role in protein folding and immune evasion. The SARS-CoV-2 S glycans differ from typical host 247 glycan processing, and therefore, might have implications in viral pathobiology and vaccine design 248 (Watanabe et al., 2020).

\section{Genome evolution of the SARS-CoV-2}

Phylogenetic comparison of coronavirus sequences from the patients of different geographical regions, and climatic conditions supports the natural origin of SARS-CoV-2 (Adachi et al., 2020; Andersen et al., 2020; Lu et al., 2020; Shereen et al., 2020; Zhou et al., 2020a). The complete genomes of the novel SARS-CoV-2 sequenced from different patients share more than 99.9\% sequence identity (Tang et al., 2020) suggesting a very recent host shift of this virus to 
256 humans ( $\mathrm{Lu}$ et al., 2020; Tang et al., 2020; Zhou et al., 2020b). The genomic analysis revealed that

257 the whole genome of SARS-CoV-2 shares $98.0 \%, 79.0 \%$ and $50.0 \%$ identity to the genomes of

258 bat SARS-related coronavirus, Bat-SARSr-CoV-RaTG13, SARS-CoV and MERS-CoV,

259 respectively (Andersen et al., 2020; Coutard et al., 2020; Lu et al., 2020; Ou et al., 2020; Tang et

260 al., 2020; Xiao et al., 2020; Zhou et al., 2020a). SARS-CoV-2 related coronaviruses have also been

261 identified in Malayan pangolins (Lam et al., 2020). Pangolin- $\mathrm{CoV}$ is $91.02 \%$ and $90.55 \%$ identical

262 to SARS-CoV-2 and BatCoV RaTG13, respectively (Lam et al., 2020; Tang et al., 2020; Xiao et

263 al., 2020). The trimeric S protein of SARS-CoV-2 and SARS-CoV are phylogenetically closely

264 related showing about 77\% aa sequence identity (Rahman et al., 2020, Yuan et al., 2020; Zhou et

265 al., 2020b Furthermore, the RBD sequence of SARS-CoV-2 is very close (99\%) to that of a

266 pangolin coronavirus (Lam et al., 2020; Tang et al., 2020). These findings therefore suggest that

267 SARS-CoV-2 is the result of the recombination of two viruses, and contains no trace of any human-

268 mediated genetic manipulation. Thousands of complete genome sequences of the SARS-CoV-2

269 have already been deposited to the global database repositories including National Center for

270 Biotechnology Information (NCBI), GSAID (global initiative on sharing all influenza data), and

271 China National Center for Bioinformation 2019 Novel Coronavirus Resource (2019nCoVR) from

272 the entire world. Phylogenetic analysis revealed that most of the SARS-CoV-2 strains from India

273 correspond to those strains isolated from China. The Brazilian (EPI_ISL_417034/Brazil/2020),

274 Australian (EPI_ISL_416412/Australia/2020), and Canadian (EPI_ISL_418827/Canada/2020)

275 SARS-CoV-2 strains also showed neighboring relationship to the Indian and Chinese strains (Fig.

276 2). Moreover, one Nepalese SARS-CoV-2 strain (EPI_ISL_410301/Nepal/2020) showed close

277 phylogenetic association with a Spanish strain (EPI_ISL_418244/Spain/2020). We also found a

278 close similarity between a South American SARS-CoV-2 strain 
279 (EPI_ISL_418262/Columbia/2020) and a North American strain (EPI_ISL_42078/USA/2020)

280 (Fig. 2). The genomic analyses of these sequences showed that some are genetically identical to

281 each other, while others carry some distinctive mutations (Islam et al., 2020; Phan, 2020).

282 Analyzing 200 whole genome sequences of the SARS-CoV-2 retrieved from the GISAID

283 (https://www.gisaid.org/), we found that the evolution of this virus is not country or territory

284 specific rather patient or ethnic group specific (Fig. 2). The ongoing pandemic outbreak of the

285 SARS-CoV-2 indicates its alarmingly rapid transmission across the globe. Determining the origin

286 and evolution of the SARS-CoV-2 is important for the surveillance, development of effective

287 interventions for controlling the epidemic, and prevention of the SARS-CoV-2. Analyses of the

288 novel SARS-CoV-2 genome and functional structures are needed to better understand its

289 molecular cross-talks with human host (Rahman et al., 2020; Zhang et al., 2020a). Regular

290 publication of pathogenic SARS-CoV-2 isolates in open science and open data sharing model,

291 reexamination of their origin and diversification patterns are becoming clear. From the initial study

292 on Wuhan COVID-19 outbreak to its rapid spread to more than 216 countries or territories in the

world, researchers suggested that this novel virus is likely to have moved to human from bats via

an intermediate host pangolin through host jump (Zhou et al., 2020a; Wu et al., 2020b; Li et al.,

2018; Sun et al., 2020). Despite having $77.38 \%$ and $31.93 \%$ sequence uniqueness among the $\mathrm{S}$ proteins of the SARS-CoV and MERS-CoV, respectively (Rahman et al., 2020), the SARS-CoVpotential for its cross-species transmission (Islam et al., 2020; Song et al., 2005; Sun et al., 2020;

Zhou et al., 2020b). The aa sequence of the RBD segment of the SARS-CoV-2 genome is $74 \%$ and $90.1 \%$ homologous to that of SARS-CoV and RaTG13, respectively (Ou et al., 2020). The 301 genome-wide phylogenetic analysis indicated that SARS-CoV-2 is closest to RaTG13, followed 
302 by GD Pangolin SARSr-CoV, GX Pangolin SARSr-CoVs, ZC45 and ZXC21, human SARS-CoV, 303 and BM48-31 (Tang et al., 2020).

Phylogenetic analysis of the recently released genomes of SARS-CoV-2 to the GISAID

305

306

307

308

309

310

311

312

313

314

315

316

317

318

319

320

321

322

323

324 (https://www.gisaid.org/) revealed that the bats' $\mathrm{CoV}$ and the human SARS-CoV-2 shares a common ancestor (Andersen et al., 2020; Zhang et al., 2020b). These considerations indeed led the researchers and virologists around the globe to phylogenetically classify the SARS-CoV-2 as a SARS-like virus (Zhang et al., 2020b). In another study, Sun et al. (2020) reported that the SARSCoV-2 shares a most recent common ancestor with BetaCoV/RaTG13/2013 (EPI_ISL_402131) due to their clustering in the same position. Conversely, Lam et al. (2020) demonstrated that the multiple putative lineages of pangolin $\mathrm{CoV}$ sequences shared $85.5 \%$ to $92.4 \%$ similarity to SARS$\mathrm{CoV}-2$. Based on these similarities, they assumed that pangolins served as a potential intermediate host (Lam et al., 2020; Sun et al., 2020). In a phylogenetic network analysis of 160 complete human SARS-CoV-2 genomes, Forster et al. (2020) reported three central variants (A, B, and C) distinguished by aa changes, which we have named A, B, and C, with A being the ancestral type according to the bat outgroup coronavirus. The A and $\mathrm{C}$ types belonged to the Europeans and Americans while the B type is the most common type in East Asia (Forster et al., 2020). Boni et al. (2020) reported that the ancestors of SARS-CoV-2 separated from the bat version, which subsequently lost the effective RBD that was present in its ancestors (and remains in SARS-CoV2). Two circumstances can plausibly explain the origin of SARS-CoV-2: (i) natural selection in humans following zoonotic transfer; and (ii) natural selection in an animal host before zoonotic transfer. However, currently available data are not sufficient enough to precisely conclude whether the virus was directly transmitted from bats to humans or indirectly through an intermediate host, pangolin. Inevitably, we need more sequence data to confirm the specific genetic identity and the 
325 origin of the SARS-CoV-2, which can be achieved by improved collection and monitoring of

326 human samples across the globe, bat, pangolin and other wild animal samples as well.

\section{Genome-wide mutations infer the evolution of SARS-CoV-2 variants}

SARS-CoV-2 are perhaps the most intriguing biological entities to adapt to new environments,

possesses traits considered beneficial for them and higher mutation rates, which are correlated with enhanced virulence and evolvability (Carrasco-Hernandez et al., 2017; Duffy, 2018; Islam et al., 2020). The ongoing rapid human to human transmission, and global spread of SARS-CoV-2 have raised some exciting questions, such as whether the evolution and host adaptation of this virus are many mutant clouds of descendants that complicates the conception of its genotyping. According and group B (256 strains) (Zhang et al., 2020b). Based on the variation of 11 nucleotide (nt) sites, Zhang et al. (2020b) speculated that the Washington strain is more like an ancestor type, and the the possible effects of genomics mutations, aa variations, and structural heterogeneity (Table 1) in the entire genomes of different strains of SARS-CoV-2 (Andersen et al., 2020; Huang et al., 2020; Islam et al., 2020; Lu et al., 2020; Phan, 2020; Yin, 2020; Walls et al., 2020). 
348 acid (aa) substitutions (Islam et al., 2020) in different ORFs, 16 aa substitutions at twelve positions

349 (Yuan et al., 2020), 935 aa replacements in the polyprotein, and 183, 33 and 222 aa substitutions

350 in the S, M and N proteins, respectively (Yin, 2020) have been reported (Table 1), which could

351 have made the viral proteins heterogeneous. In a recent study, van Dorp and co-authors reported

352198 mutations that appear to have independently occurred more than once, which may hold clues

353 to how the virus is adapting (van Dorp et al., 2020). Islam et al. (2020) reported 12 aa substitutions

354 in the RBD at 331 to 524 residues of S1 subunit in different SARS-COV-2 strains of Wales, USA,

355 Shenzhen, Hong Kong, Shanghai, Guangdong, Finland, and France. Similarly, Sarkar et al. (2020)

356 identified a unique mutation in the S glycoprotein (A930V) in the Indian SARS-CoV-2 strain,

357 which was absent in other related SARS-CoV-2 strains from different geographical regions.

358 Six corresponding RBD aa (residue positions: Y442, L472, N479, D480, T487 and Y4911

359 in SARS-CoV, and L455, F486, Q493, S494, N501 and Y505 in SARS-CoV-2) have been reported

360 to be critical for binding to ACE2 receptors, and determining the host range (Andersen et al., 2020;

361 Islam et al., 2020). On the other hand, Andersen et al. (2020) reported that five of these six residues

362 differ between SARS-CoV-2 and SARS-CoV. The RBD region (aa position: 338-530) of the

363 SARS-CoV-2 genome individually faced aa mutations at 72 different positions in 394 strains, and

364 the S1 and S2 subunits of the spike protein undergo 331 and 274 number of positional mutations,

365 respectively (Wrapp et., al 2020). Mutations, insertions and deletions can occur near the S1-S2

366 junction of coronaviruses, which shows that the polybasic cleavage site can arise by a natural

367 evolutionary process (Andersen et al., 2020). The aa substitutions related to asparagine in the RBD,

368 and/or in S1/2 subdomains adjacent to the glycosylated sites may affect the glycosylation shield,

369 folding of S protein, host-pathogen interactions, viral entry and finally immune modulation, thus

370 antibody recognition and viral pathogenicity (Ou et al., 2020a; Watanabe et al., 2020). Three 
371 mutation types circulating in Wuhan, Shenzhen, Hong Kong, and France, displayed enhanced

372 structural stability along with higher human ACE2 receptor affinity of the S protein, indicating

373 these mutants may have acquired increased infectivity to humans (Ou et al., 2020b; Wang et al.,

374 2020c). It is likely that a high mutation rate in S protein, coupled with strong natural selection, has

375 shaped the identical functional aa residues between SARS-CoV-2 and GD Pangolin-CoV, as

376 proposed previously (Lam et al., 2020; Tang et al., 2020). In addition to site-specific mutations in

377 the spike protein, several deletions in the ranged nucleotides were also reported in the polyprotein,

378 ORF10 and 3'-UTR of the genome of SARS-CoV-2 strains reported from Japan, USA, England,

379 Canada, Netherlands, Wuhan and Australia (Islam et al., 2020). The single N501T mutation in

380 SARS-CoV-2's S protein may have significantly enhanced its binding affinity for ACE2 (Shereen

381 et al., 2020). Furthermore, deletion of 5 aa (675-679 aa: QTQTN) at the upstream of the polybasic

382 cleavage site of S1-S2, and $21 \mathrm{nt}$ at 23596-23617 positions in the polybasic cleavage site in clinical

383 samples and cell-isolated virus strain likely benefit the SARS-CoV-2 replication or infection in

384 vitro, and also strong purification selection in vivo (Liu et al., 2020). These mutations, deletions

385 and/or substitutions in the polyprotein, S, M and E proteins of the SARS-CoV-2 genome can

386 potentially influence the tertiary structures and functions of the associated proteins, and ultimately

387 affect the viral adaptation to human, host-virus interactions, attenuation, pathogenicity, and

388 immune-modulations (Islam et al., 2020; Phan, 2020; Xu et al., 2020; Qu et al., 2020; Zhou et al., 389 2020b).

390 The emerging rapid community transmission, and global spread of COVID-19 have raised 391 intriguing questions whether the evolution and adaptation of the SARS-CoV-2 in diverse 392 geographic and climatic conditions driven by aa mutations, deletions and/or replacements (Bal et 393 al., 2020; Islam et al., 2020; Pachetti et al., 2020). Hitherto, the exact role of geo-climatic condition 
394 on global pandemics of SARS-CoV-2 is largely unknown. Nevertheless, it would be worth keeping

395 in mind that this novel disease originated from the wildlife before they spread to humans (Harvey,

396 2020). The ability of the different strains of SARS-CoV-2 strains for swift adaptations to the

397 diverge environments could be linked to their geographical distributions. Conversely,

398 phylogenomic analysis of three super-clades (S, V, and G) isolated from the outbreaks of distinct

399 geographic locations (China, USA and Europe) could not clearly reflect the hypothetical ongoing 400 adaptation of SARS-CoV-2, which alternately refer to mere genetic drift and founder effects due 401 to rapid spreading of the virus (Chiara et al., 2020). Though not yet studied well, evidences 402 suggested that the transmission of SARS-CoV-2 infections and per day mortality rate from this 403 infection is positively associated with weather conditions, and diurnal temperature range (DTR) 404 (Brassey et al., 2020; Su et al., 2020).

405

\section{Diagnostic tools for the COVID-19}

407

The clinical symptoms expressed by SARS-CoV-2 patients are non-specific, and thus, cannot be used for an accurate diagnosis. Only molecular techniques are able to specifically detect specific pathogen in a convenient way. A rapid, specific and convenient diagnostic protocol might play a vital role in the containment of the SARS-CoV-2, helping the rapid implementation of management of the disease that limit the spread through case identification, isolation, and contact tracing (Drew et al., 2020). The complete genome sequence data of the virus was publicly available within weeks of the first outbreak in Wuhan. It helped researcher to target specific genes for the development of nucleic acid test within three weeks. The on-going outbreaks of SARS-CoV-2 could also be diagnosed more accurately using metagenomics approaches in a wider range clinical

416 samples like other infectious diseases (Hoque et al., 2019; Lam et al., 2020). 

of bat coronavirus RaTG13 (Zhou et al., 2020a). Later consistent detection of SARS-CoV-2 in saliva was published by To et al. (2020). Several groups and countries developed many diagnostic

422 protocols targeting or using nucleic acid tests or protein/antibody, loop-mediated amplified technique, imaging techniques (CT-scan) or CRISPR-Cas mediated technology (Table 2)

424 (Broughton et al., 2020; Zhang et al., 2020c). Recently, more and more user-friendly molecular tests are on the horizon for SARS-CoV-2 RNA screening, as for example using Heating Interspaced Short Palindromic Repeats (CRISPR) methods (Broughton et al., 2020).

by several groups targeting different genes. For example, Chan et al. (2020) developed three methods of RT-PCR, and of these assays, the COVID-19-RdRp/Hel (RNA-dependent RNA polymerase $(R d R p) /$ helicase) assay had the lowest limit of detection in vitro (1.8 TCID50/ml with genomic RNA and 11.2 RNA copies/reaction with in vitro RNA transcripts). This method was validated in testing 273 suspected patients where 15 patients were confirmed as SARS-CoV-2 positive. This method targeted the $R d R p / \mathrm{Hel}, S$, and $N$ genes of SARS-CoV-2 with that of the reported RdRp-P2 assay which is used in more than 30 European laboratories. Huge improvements have been achieved in the RT-PCR methods since it first development. However, there are some drawbacks of the RT-PCR, as for example kits can give some false-negative results, dependency on swab sampling and extraction method, and required highly skilled personnel, sophisticated 439 facilities and equipment (Nuccetelli et al., 2020). The non-invasive radiographic technique, CT- 
440 scan, is more sensitive than RT-PCR, and has been widely used worldwide for the detection of

441 SARS-CoV-2 (Nuccetelli et al., 2020). In fact, the chest radiograph assessment of the SARS-CoV-

4422 patients resembled many features of community-acquired pneumonia (CAP) that are similar to

443 other organisms including SARS-CoV and avian influenza A H5N1 (Cheng et al., 2004). Through

444 analysis of the data of 1,014 patients in China, CT scan was found to be sensitive than RT-PCR

445 for diagnosis of SARS-CoV-2 (Ai et al., 2020). The chest CT imaging showed higher positive

446 rates $(88 \%, 888 / 1014)$ in diagnosing the COVID-19 suspected patients compared to the

447 confirmatory rates $(59 \%, 601 / 1014)$ of RT-PCR assays. The sensitivity of chest CT imaging for

448 COVID-19 was 97\%, where RT-PCR was used as a standard reference (Ai et al., 2020).

Developing plug-and-play diagnostics to manage the SARS-CoV-2 outbreak would also

450 be useful in preventing future epidemics. A recently developed Abbott ID Now ${ }^{\mathrm{TM}}$ COVID-19 test

451 has been found to be very convenient, and can detect SARS-CoV-2 in 5 min only. Similarly,

452 several serological assays have been developed since the beginning of COVID-19 pandemic,

453 including point-of-care test (POCT)-fluorescence assays, enzyme-linked immunosorbent assays

454 (ELISA), rapid antibody immunochromatographic tests, and chemiluminescence immunoassays

455 (CLIAs) (Nuccetelli et al., 2020). Serological tests are cheaper than molecular tests, require a

456 shorter analytical time, and productivity can be much greater than molecular tests. However, these

457 tests to detect antibodies against viral antigens are not yet widely used during this pandemic

458 probably due to longer time (7-14 days) required for the detectable antibodies in the patient's

459 blood. In fact, production of antibody in human bloods requires weeks after infection by the SARS-

460 CoV-2 which limits the use of antibody-based test methods for the early detection of the disease.

461 A research group of Peking University developed a new method for rapid construction of

462 transcriptome sequencing library of Sequencing HEteRo RNA-DNA-hYbrid (SHERRY), which 
463 is helpful for rapid sequencing of SARS-CoV-2 (Di et al., 2020). They showed that Tn5 464 transposase, which randomly binds and cuts double-stranded DNA, can directly fragment and 465 prime the RNA/DNA heteroduplexes generated by reverse transcription. The primed fragments 466 are then subject to PCR amplification. This provides an approach for simple and accurate RNA 467 characterization and quantification.

468 The recent outbreak of the SARS-CoV-2 can be diagnosed using qPCR, but inadequate 469 access to reagents and equipment has slowed disease detection. To rapidly diagnose the disease, 470 Zhang group of MIT developed a test paper for rapid detection of SARS-CoV-2 in one hour by 471 using SHERLOCK (Specific High Sensitivity Enzyme Reporter UnLOCKing) technology. This 472 technology may be used widely after clinical trials (Zhang et al., 2020c). This technique used 473 synthetic SARS-CoV-2 $S$ and ORFlab genes for the diagnosis and no clinical specimen has yet 474 been tested.

In the process of the development of new technique, an exciting improvement is the DZ476 Lite SARS-CoV-2 CLIA IgM and IgG tests established by Diazyme, USA. This technique has 477 received FDA EUA approval (https://bit.ly/2UXlils). The molecular principle of this test is a CLIA 478 that run on an automated Diazyme DZ-Lite 3000 Plus chemiluminescence analyzer with a 479 throughput of 50 tests/h. Similarly, Snibe, China, has developed automated CLIA tests on 480 MAGLUMI CLIA analyzers for the detection of IgG and IgM in the patient sample in 30 min 481 (https://bit.ly/2JXGMZm). The major advantages of automated CLIA analyzers based COVID-19 482 assays compared to rapid LFIA tests is the very high throughput of samples that can be analyzed 483 and the ability to perform more clinical tests for other biomarkers, such as C-reactive protein 484 (CRP), which also need to be monitored in COVID-19 suspects. The rapid, convenient, low cost 485 and specific serological and automated tests are urgently needed to be distributed worldwide 
486 especially in the developing countries for testing higher number of patients to tackle this highly

487 contagious disease.

488

489 Antivirals for the pandemic SARS-CoV-2 virus: vaccines and therapeutics

490

491

492

493

494

495

496

497

498

499

500

501

502

503

504

505

506

507

508

Despite several public health measures such as case isolation, identification and follow-up of contacts, environmental disinfection, social distance, and the use of personal protective equipment have been introduced (Wei and Ren, 2020), in the absence of any antivirals (Kalita et al., 2020; Rahman et al., 2020; Wang et al., 2020b), the disease is spreading at an alarming rate. The new cases of active acute infections are being added to the open COVID-19 database such as NCBI, GSAID, and also to the China National Center for Bioinformation 2019 Novel Coronavirus Resource (2019nCoVR) (Fig. 3), every day, as the case count globally skyrockets. Researchers from across the globe are desperately working round the clock to find ways to slow the spread of the novel coronavirus and to find an effective treatment to control this fatal viral disease. Though, more than 200 clinical trials of SARS-CoV-2 treatments or vaccines that are either ongoing or recruiting patients (Zhou et al., 2020b), till now no recommended therapeutic drug or vaccines are available for the treatment of COVID-19. The WHO suggested and acknowledged the enormous possibilities of drug repurposing approach. As for example, in the mid of March 2020, the WHO announced the 'SOLIDARITY' clinical trial for COVID-19 treatments (Khan et al., 2020b).

At the outset of the epidemic in Wuhan, China, COVID-19 confirmed patients were treated with interferons- $\alpha$ nebulization, broad-spectrum antibiotics, and few antiviral drugs to reduce the viral load (Shereen et al., 2020; Wang et al., 2020b), however, only remdesivir (GS-5734) has shown promising impact against the virus (Wang et al., 2020b). Since then, various other antiviral drugs including nafamostat, nitazoxanide, ritonavir, aak1, baricitinib, arbidol, ribavirin, penciclovir, 
509 chloroquine, favipiravir (T-750) or avigan, hydroxychloroquine and chloroquine EIDD-2801 are

510 being tested in clinical trials (Martinez, 2020; Liu et al., 2020; Wang et al., 2020b). The Food and

511 Drug Administration (FDA) announced the cancellation of the use of hydroxychloroquine in the

512 emergency treatment of coronavirus since this anti-malarial drug can cause serious side effects in

513 patients with having health risks. Clinical trials with the nucleotide analog remdesivir

514 (ClinicalTrials.gov: NCT04257656, NCT04252664, NCT04280705), and protease inhibitors

515 (ClinicalTrials.gov: NCT04255017, NCT04276688) have been done in China and the United

516 States. Remdesivir works against coronaviruses closely related to SARS-CoV-2 in animal models

517 (de Wit et al., 2020; Sheahan et al., 2020a). Remdesivir's mechanism of action as a nucleotide

518 analog is not clear, however, it targets viral RNA polymerase, and terminates RNA synthesis, leads

519 to incorporation mutagenesis, or both (Amanat and Krammer, 2020). In addition, a combination

520 of the two protease inhibitors, lopinavir and ritonavir, are also being tested in clinical trials (e.g.,

521 ClinicalTrials.gov: NCT04264858), and these drugs can inhibit the cytochrome P450 (Amanat and

522 Krammer, 2020; Cao et al., 2020). Antiviral arbidol, a fusion inhibitor has also been under ongoing

523 clinical trials (ClinicalTrials.gov: NCT04287686), and dosing with this drug may act through

524 human ACE2 receptor to neutralize the virus, and prevent lung damage (Amanat and Krammer,

525 2020). Another interesting option is the use of convalescent serum as treatment; clinical trials to

526 test this are ongoing in China (ClinicalTrials.gov: NCT04264858, placebo control, not recruiting

527 yet), and compassionate use of this strategy has recently started in the US (e.g. at Mount Sinai

528 Medical Center, NY). Likewise, transgenic cows derived polyclonal human immunoglobulin G

529 (IgG) could be used, and has been tested for safety in clinical trials (ClinicalTrials.gov:

530 NCT02788188). This strategy was successful for MERS-CoV in animal models (Luke et al.,

531 2016). Many of these trials will have results within few months, and if remdesivir (produced by 
532 Gilead) and/or lopinavir plus ritonavir (produced by AbbVie as Kaletra and Aluvia, respectively)

533 show effectiveness, they could potentially be used widely. Considerate use of these drugs has

534 already been reported for SARS-CoV-2 infections (Holshue et al., 2020). The orally bioavailable

535 modified nucleoside analog, $\beta$-D-N4-hydroxycytidine (NHC, EIDD-1931), is a broad-spectrum

536 antiviral drug against various unrelated RNA viruses including influenza, Ebola, CoV, and

537 Venezuelan equine encephalitis virus (VEEV) (Reynard et al., 2015; Agostini et al., 2019; Toots

538 et al., 2019). This proven NHC/EIDD-2801 against multiple coronaviruses showed potential

539 antiviral activity against SARS-CoV-2, and recommended for future zoonotic outbreaks of

540 coronaviruses (Sheahan et al., 2020b). Dexamethasone being a steroid reduces inflammation and

541 suppressing immune activation of immune agents, could be inducing the anti-inflammatory effects,

542 and reducing the secretion of cytokines into the lungs (Kupferschmidt, 2020). In a recent recovery

543 trial, COVID-19 patients who received dexamethasone for 10 days had reduced deaths by one-

544 third (Kupferschmidt, 2020). Despite, there are several reports of using corticosteroids in the

545 treatment of SARS-CoV-2, the available data on safety and efficacy of corticosteroids in COVID-

54619 is controversial since it can delay virus clearing (Li et al., 2020b).

547 Immunoprophylaxis through passive transfer of antibodies is regarded as an effective method

548 for clinical treatment of infectious diseases. For example, the use of versatile class of mAbs is a

549 new era in infectious disease prevention. This passive immunization overcomes many drawbacks

550 associated with serum therapy and intravenous immunoglobulins preparations in terms of

551 specificity, purity, low risk of blood-borne pathogen contamination and safety (Ter Meulen., 2006;

552 Shanmugaraj et al., 2020). Several earlier studies reported the successful generation of neutralizing

553 antibodies in mice against SARS-CoV through experimental vaccination or passive transfer of

$554 \mathrm{mAb}$, and subsequent reduction of viral replication (Traggiai et al., 2004; Sui et al., 2005; Ter 
555 Meulen., 2006). Thus, mAbs with potent neutralizing activity against SARS-CoV-2 infections

556 could become promising candidates for both prophylactic and therapeutic interventions

557 (Shanmugaraj et al., 2020; Zhou et al., 2020b). Though several polyclonal antibodies from

558 recovered SARS-CoV-2-infected patients have been used to treat SARS-CoV-2 infection, but no

559 SARS-CoV-2-specific neutralizing monoclonal antibodies (mAbs) have been reported so far.

560 Researches are ongoing to develop $\mathrm{mAbs}$ and/or their functional fragments as putative

561 prophylactic or therapeutic agents to prevent SARS-CoV-2 infections (Jiang et al., 2020). The

562 genome of the SARS-CoV-2 virus is closely related to SARS-CoV, and their spike proteins share

563 more than $75 \%$ aa sequence identity (Rahman et al., 2020, Yuan et al., 2020; Zhou et al.,2020b).

564 Researchers have attempted to discover SARS-CoV natural antibodies (nAbs) with potential cross-

565 reactivity, and/or cross-neutralizing activity against SARS-CoV-2 infections (Jiang et al., 2020).

566 Remarkably, a SARS-CoV-specific human mAb, CR3022, could bind potently with 2019-nCoV

$567 \mathrm{RBD}(\mathrm{KD}$ of $6.3 \mathrm{nM})$, and recognize an epitope on the RBD that does not overlap with the ACE2-

568 binding site (Tian et al., 2020). Although, some of the potent SARS-CoV-specific neutralizing

569 antibodies (e.g. m396, CR3014) that target the ACE2 binding site failed to bind SARS-CoV-2 S

570 protein, the CR3022 might have the potential to be developed as candidate therapeutics, alone or

571 in combination with other nAbs, for the prevention and treatment of SARS-CoV-2 infections (Tian

572 et al., 2020). Furthermore, SARS-CoV RBD-specific polyclonal antibodies have cross-reacted

573 with the SARS-CoV-2 RBD protein, and cross-neutralized SARS-CoV-2 infection in HEK293T

574 cell line firmly expressing the human ACE2 receptor, opening avenues for the development of

575 SARS-CoV RBD-based vaccines that might eventually prevent SARS-CoV-2 and SARS-CoV

576 infection (Jiang et al., 2020). A human mAb, 47D11, has been developed that binds to a conserved

577 epitope on the spike RBD, and has the ability to cross-neutralize SARS-CoV and SARS-CoV-2 
578 through a mechanism of receptor-binding inhibition (Wang et al., 2020d). This antibody (47D11)

579 would be useful for development of antigen detection tests, and serological assays targeting SARS-

580 CoV-2 (Wang et al., 2020d). It is plausible that SARS-CoV RBD-targeting nAbs could be applied

581 for prophylaxis and treatment of SARS-CoV-2 infection in the absence of SARS-CoV-2-specific

582 vaccines and antibodies, but demands for robust testing. Even as the hunt for a vaccine to treat

583 COVID-19 continues, a classic adaptive immunotherapy known as convalescent plasma (CP)

584 therapy that was successfully applied over the past two decades to treat SARS, MERS, and 2009

585 H1N1 outbreaks with satisfactory efficacy and safety (Cheng et al., 2005; Hung et al., 2009; Ko et

586 al., 2018) holds good promise. In a recent pilot study, Duan et al. reported that CP therapy was

587 found to be well tolerated and could potentially improve the clinical outcomes through neutralizing

588 viremia in severe COVID-19 cases (Duan et al., 2020). One dose of CP with a high concentration

589 of neutralizing antibodies can rapidly reduce the viral load, and tends to improve clinical outcomes.

590 However, the optimal dose and treatment time point, as well as the definite clinical benefits of CP

591 therapy should be further investigated in randomized clinical studies.

592 Vaccines are the most effective and economical means to prevent and control the infectious

593 viral diseases (Zhang et al., 2020a). There are multiple attempts in progress to develop such a

594 vaccine following previously described strategies for SARS-CoV and MERS-CoV which might

595 be effective against SARS-CoV-2. Currently, more than 90 vaccines are being developed against

596 SARS-CoV-2 by different research teams in companies and universities across the world. Major

597 vaccine platforms include traditional recombinant protein, replicating and non-replicating viral

598 vectors, and nucleic acid DNA and mRNA approaches (Corey et al. 2020). At least six groups

599 have already begun injecting formulations into volunteers in safety trials; others have started

600 testing in animals. A research group led by Professor Sarah Gilbert of Oxford University 
601 developed an adenovirus (ChAdOx1)-based vaccine, the 'ChAdOx1 nCoV-19' targeting the spike 602 protein of the SARS-CoV-2, and two healthy volunteers have been immunized on 24 April, 2020 603 as the first clinical trial of this vaccine (Lane, 2020). Gao et al. (2020) have developed an 604 inactivated vaccine candidate (PiCoVacc), which induced SARS-CoV-2-specific neutralizing 605 antibodies in mice, rats and non-human primates. However, inactivated and attenuated virus 606 vaccines have a wide range of disadvantages and side effects including inappropriate for highly 607 immunosuppressed individuals (Shang et al., 2020b), phenotypic or genotypic reversion is possible 608 and can still cause some disease (Regla-Nava et al., 2015). Alternatively, putative protective 609 antigen/peptides vaccine candidate for SARS-CoV-2 should be considered on the basis 610 immunogenicity (Wang et al., 2020d). Moreover, subunit vaccines may be target specific, well611 defined neutralizing epitopes with improved immunogenicity and/or efficacy (Zhang et al., 2020a; 612 Wang et al., 2020e).

613 With the advancement in immunoinformatics and computational biology, it is now possible to 614 accelerate the vaccine development (Rahman et al., 2020; Zhang et al., 2020a), and these methods 615 have surpassed the conventional methods. Quite a good number of vaccines are in the pipeline 616 against SARS-CoV-2. An mRNA-based vaccine (mRNA-1273) co-developed by Moderna (a 617 company based in Cambridge, Massachusetts) and the Vaccine Research Center at the National 618 Institutes of Health, like many of the other SARS-CoV-2 vaccines in development, is designed to 619 train the immune system to make antibodies that recognize and block the $\mathrm{S}$ protein that the virus 620 uses to enter human cells (Callaway, 2020). And this vaccine is currently the furthest along, and 621 has already started the phase I trial (ClinicalTrials.gov: NCT04283461) in human and animals 622 (Amanat and Krammer, 2020). Preclinical trials of another DNA-based vaccine candidate, INO6234800 demonstrated as a promising candidate to protect against the novel coronavirus SARS-CoV-2 
624 (Inovio IP, 2020). INO-4800 targets the major surface antigen S protein of SARS-CoV-2 virus, 625 and induced antibodies to block SARS-CoV-2 S binding to the host ACE2 receptor. Vaccination 626 with INO-4800 generated near-100\% seroconversion, robust binding and neutralizing antibody as 627 well as T cell responses in mice and guinea pigs (Inovio IP, 2020). The Centre for Disease Control 628 and Prevention (CDC), China is working to develop an inactivated virus vaccine (Cheung, 2020). 629 An mRNA-based vaccine's sample prepared by Stermirna Therapeutics will be available soon 630 (Xinhua, 2020). The GeoVax and BravoVax (Wuhan, China) is working to develop a Modified 631 Vaccina Ankara (MVA) based vaccine (Geo-Vax, 2020). In addition, the Clover 632 Biopharmaceuticals is trying to develop a recombinant 2019-nCoV S protein subunit-trimer based 633 vaccine (Clover B, 2020). Another biopharmaceutical company Curevac (Germany) is working on 634 a similar vaccine but is still in the pre-clinical phase. Additional approaches in the pre-clinical 635 stage include viral-vector-based vaccines (focused on the S protein, e.g., Vaxart, Geovax, 636 University of Oxford, and Cansino Biologics), recombinant-protein-based vaccines (focused on 637 the S protein, e.g., ExpresS2ion, iBio, Novavax, Baylor College of Medicine, University of 638 Queensland, and Sichuan Clover Biopharmaceuticals), DNA vaccines (focused on the S protein, 639 e.g., Inovio and Applied DNA Sciences), live attenuated vaccines (Codagenix with the Serum 640 Institute of India, etc.), and inactivated virus vaccines (Amanat and Krammer, 2020). All of these 641 approaches have advantages and disadvantages, thus, it is not possible to predict which strategy 642 will be faster or more successful. Two multinational company, Johnson \& Johnson (J\&J) (Johnson 643 \& Johnson, 2020) and Sanofi (2020) recently joined efforts to develop SARS-CoV-2 vaccines 644 using an experimental adenovirus vector platform, and a process similar to the process used for 645 their approved Flublok recombinant influenza virus vaccine (Zhou et al., 2006). This vaccine may 
646 be available within months, if not years, from being ready for use in the human population (Amanat 647 and Krammer, 2020).

648 Being an RNA virus, genome-wide nucleotide mutations and aa mutations and/or substitutions 649 (Table 1) have already been reported in different SARS-CoV-2 strains from across the globe 650 (Huang et al., 2020; Islam et al., 2020; Phan, 2020; Yin, 2020; Wang et al., 2020e). Therefore, it 651 is critical to develop vaccines with strong efficacy and safety targeting this SARS-CoV-2 to 652 prevent its infection in humans. The structural divergence in the RBD and NTD segments of the S 653 protein in SARS-CoV-2 is main focus of vaccine candidate designing, selection, and development 654 (Rahman et al., 2020). Therefore, multi-epitope based vaccines targeting the full-length S protein 655 and its structural domains (RBD, NTD, S1 and S2 subunits), M, E and N proteins can play a great 656 role in fighting against this SARS-Cov-2 virus rather than a single-epitope vaccine (Rahman et al., 657 2020; Zhang et al., 2020a).

658

659 Conclusions and perspectives

660

The emergence of the novel, pathogenic SARS-CoV-2 in the Wuhan city of China in

661

662

663

664

665

666

667

668

December 2019, and its rapid national and international spread has created a global health emergency. Genome sequences of a large number of strains of SARS-CoV-2 have been published, and all the research data on this new virus are publicly available. The genomic features described in this review is based on the recent reports of the infectiousness and transmissibility of SARSCoV-2 in humans. Currently, evidence supports the natural zoonotic origin of the SARS-CoV-2, not a purposefully manipulated laboratory product. Moreover, identifying the closest viral relatives of SARS-CoV-2 circulating in animals will greatly assist future studies of viral function. Indeed, the availability of the RaTG13 bat and Malayan Pangolin sequences helped reveal key RBD 
669 mutations and the polybasic furin cleavage sites. Genome-wide annotations of a wider range of

670 sequences (50-2500) revealed considerable number of mutations throughout the SARS-CoV-2

671 genome, which includes both mismatch and deletion mutations both in translated and untranslated

672 regions. Moreover, the identification of the conformational changes in mutated protein structures

673 and untranslated cis-acting elements is of significance for studying the virulence, pathogenicity

674 and transmissibility of SARS-CoV-2. The discovery of specific diagnostic tool targeting specific

675 genes of the genome of SARS-CoV-2 within weeks of the outbreak of the disease in China was a

676 phenomenal research success which has been playing vital role in tackling this highly contagious

677 disease. Although real-time RT-PCR methods targeting specific genes have widely been used to

678 diagnose the SARS-CoV-2 infected patients, however, recently developed more convenient, rapid,

679 and specific diagnostic tools targeting $\operatorname{IgM} / \operatorname{IgG}$ or newly developed plug and play methods should

680 be available especially for the resource-poor developing countries. Therefore, the development of

681 an effective vaccine is one of the most pressing needs to contain the ongoing pandemic of SARS-

$682 \mathrm{CoV}-2$, to reducing morbidity and mortality in infected population, and also preparation for long

683 term prevalence of the SARS-CoV-2 virus. Several approaches for vaccines and antivirals

684 targeting human coronaviruses are in developmental stages, which could be safely and effectively

685 used against the current as well as future epidemics. We can assume that potential targets for

686 development of drugs and multiepitope-based chimeric peptide vaccines against this newly

687 emerging lineage B beta-CoV, SARS-CoV-2 will be available within a reasonable period of time.

688 However, vaccine delivery modality and immunization strategy should be ensured through rapid 689 human and animal-based trails before commercialization. Nevertheless, owing to the different 690 experimental methods, sample sizes, sample sources, and research perspectives of various studies, 691 results have been inconsistent, or relate to an isolated aspect of the virus or the disease it causes. 
692 At present, systematic summary data on the SARS-CoV-2 are limited. This review summarizes

693 new knowledge on genomics, genome evolution, developed diagnostic methods and progress in

694 development of vaccine or therapeutics, from multiple perspectives, with the aim of gaining a

695 better overall understanding, prevention and control of the disease. This review also discusses on

696 scopes for further research and effective management and surveillance of the emerging SARS-

697 CoV-2 pandemics.

698

699

700

701

\section{Authors Contributions}

702

TI: Involved in conceived the idea, drafted and edited the manuscript; MNH: Conceived 703 and wrote manuscript, prepared Figures and Tables; AC, MAMA and MAH: Critically edited the 704 manuscript.

705

706

707

The authors declared no competing interests.

708

709

710

This review article has no ethical issues.

711

712

\section{Data Availability Statement}

All data used in this manuscript are available in the manuscript as Figures and Tables. This

714 is a literature review having no raw data. 


\section{Funding}

718

The authors received no funding for the review article.

719

720

721

722

723

724

725

726

727

728

729

730

731

732

733

\section{References}

Abdelmageed MI, Abdelmoneim AH, Mustafa MI, Elfadol NM, Murshed NS, Shantier SW, Makhawi AM. 2020. Design of multi epitope-based peptide vaccine against E protein of human 2019-nCoV: An immunoinformatics approach. BioMed Res. Internatl. 2683286.

Adachi S, Koma T, Doi N, Nomaguchi M, Adachi A. 2020. General Commentary: Origin and evolution of pathogenic coronaviruses. Front. Immunol. 11, 811.

Agostini ML, Pruijssers AJ, Chappell JD, Gribble J, Lu X, Andres EL, Bluemling GR, Lockwood MA, Sheahan TP, Sims AC, Natchus MG. 2019. Small-Molecule Antiviral $\beta$-d-N4-Hydroxycytidine Inhibits a Proofreading-Intact Coronavirus with a High Genetic Barrier to Resistance. J. Virol. 93, 24. 
736

737

738

739

740

741

742

743

744

745

746

747

748

749

750

751

752

753

754

755

756

757

758

Ahmed SF, Quadeer AA, McKay MR. 2020. Preliminary identification of potential vaccine targets for the COVID-19 coronavirus (SARS-CoV-2) based on SARS-CoV immunological studies. Viruses 12(3), 254.

Ai, T., Yang Z, Hou H, Zhan C, Chen C, Lv W, Tao Q, Sun Z, Xia L. 2020. Correlation of chest CT and RT-PCR testing in coronavirus disease 2019 (COVID-19) in China: a report of 1014 cases. Radiology, http://doi.org/10.1148/radiol.2020200642.

Almofti YA, Abd-elrahman KA, Gassmallah SA, Salih MA. 2018. Multi Epitopes Vaccine Prediction against Severe Acute Respiratory Syndrome (SARS) Coronavirus Using Immunoinformatics Approaches. Am. J. Microbiol. Res. 6(3), 94-114.

Amanat F, Krammer F. 2020. SARS-CoV-2 vaccines: status report. Immunity 52(4), 583-589.

Andersen KG, Rambaut A, Lipkin WI, Holmes EC, Garry RF.2020. The proximal origin of SARS-CoV-2. Nat. Med. 26(4), 450-2.

Anonymous 2020a. Division of Viral Diseases. CDC 2019-Novel Coronavirus (2019-nCoV)

Real-Time RT-PCR Diagnostic Panel; Division of Viral Diseases, U.S. Centers for

Disease Control and Prevention, 2020.

Anonymous 2020b. Specific Primers and Probes for Detection 2019 Novel Coronavirus;

China National Institute For Viral Disease Control and Prevention, 2020.

Anonymous 2020c. Detection of 2019 Novel Coronavirus (2019-nCoV) in Suspected Human Cases by RT-PCR; School of Public Health, Hong Kong University.

Armijos-Jaramillo V, Yeager J, Muslin C, Perez-Castillo Y. 2020. SARS-CoV-2, an evolutionary perspective of interaction with human ACE2 reveals undiscovered amino acids necessary for complex stability. Evol. Appl. https://doi.org/10.1101/2020.03.21.001933. 

Microbiol. Res. 4(4), 101-21.

Bastola A, Sah R, Rodriguez-Morales AJ, Lal BK, Jha R, Ojha HC, Shrestha B, Chu DK,

Poon LL, Costello A, Morita K. 2020. The first 2019 novel coronavirus case in Nepal. The Lancet Infect. Dis. 20(3), 279-280.

Boni MF, Lemey P, Jiang X, Lam TT, Perry B, Castoe T, Rambaut A, Robertson DL. 2020. Evolutionary origins of the SARS-CoV-2 sarbecovirus lineage responsible for the COVID-19 pandemic. bioRxiv. doi: https://doi.org/10.1101/2020.03.30.015008.

Broughton JP, Deng X, Yu G, Fasching CL, Servellita V, Singh J, Miao X, Streithorst JA, of SARS-CoV-2. Nat. Biotech. 1-5. A trial of lopinavir-ritonavir in adults hospitalized with severe Covid-19. N. Engl. J. Med. NEJMoa2001282. HW, Choi GK. 2020. Improved molecular diagnosis of COVID-19 by the novel, highly sensitive and specific COVID-19-RdRp/Hel real-time reverse transcription-polymerase chain reaction assay validated in vitro and with clinical specimens. J. Clin. Microbiol. 23, 58(5). 
780

781

782

783

784

785

786

787

788

789

790

791

792

793

794

795

796

797

798

799

800

Chen N, Zhou M, Dong X, Qu J, Gong F, Han Y, Qiu Y, Wang J, Liu Y, Wei Y, Yu T. 2020. Epidemiological and clinical characteristics of 99 cases of 2019 novel coronavirus pneumonia in Wuhan, China: a descriptive study. Lancet 395, 507-13.

Cheng VC, Tang BS, Wu AK, Chu CM, Yuen KY. 2004. Medical treatment of viral pneumonia including SARS in immunocompetent adult. J. Infect. 49(4), 262-273.

Cheng Y, Wong R, Soo YO, Wong WS, Lee CK, Ng MH, Chan P, Wong KC, Leung CB, Cheng G. 2005. Use of convalescent plasma therapy in SARS patients in Hong Kong. Eur. J. Clin. Microbiol. Infect. Dis. 24, 44-46.

Clover B. 2020. Clover initiates development of recombinant subunit- trimer vaccine for wuhan coronavirus (2019-ncov). [Cited 20206 March].

Corman VM, Landt O, Kaiser M, Molenkamp R, Meijer A, Chu DK. et al. 2020. Detection of 2019 novel coronavirus (2019-nCoV) by real-time RT-PCR. Euro Surveill. 25(3), 2000045.

Corey L, Mascola JR, Fauchi AS, Collins FS. 2020. A strategic approach to COVID-19 vaccine R\&D. Science 368(6494), 948-950.

Coutard B, Valle C, de Lamballerie X, Canard B, Seidah NG, Decroly E. 2020. The spike glycoprotein of the new coronavirus 2019-nCoV contains a furin-like cleavage site absent in CoV of the same clade. Antiviral Res. 176, 104742.

Di L, Fu Y, Sun Y, Li J, Liu L, Yao J, Wang G, Wu Y, Lao K, Lee RW, Zheng G. 2020. RNA sequencing by direct tagmentation of RNA/DNA hybrids. Proc. Natl. Acad. Sci. USA. 117(6), 2886-93. 
801 Drew DA, Nguyen LH, Steves CJ, Menni C, Freydin M, Varsavsky T, Sudre CH, Cardoso 802 MJ, Ourselin S, Wolf J, Spector TD. 2020. Rapid implementation of mobile technology for real-time epidemiology of COVID-19. Science eabc0473.

804

805

806

807

808

809

810

811

812

813

814

815

816

817

818

819

820

821

822

Duan K, Liu B, Li C, Zhang H, Yu T, Qu J, Zhou M, Chen L, Meng S, Hu Y, Peng C. 2020. Effectiveness of convalescent plasma therapy in severe COVID-19 patients. Proc. Natl. Acad. Sci. USA. 117(17), 9490-9496.

Forster P, Forster L, Renfrew C, Forster M. 2020. Phylogenetic network analysis of SARSCoV-2 genomes. Proc. Natl. Acad. Sci. USA. https://doi.org/10.1073/pnas.2004999117.

Freundt EC, Yu L, Goldsmith CS, Welsh S, Cheng A, Yount B, Liu W, Frieman MB, Buchholz UJ, Screaton GR, Lippincott-Schwartz J. 2010. The open reading frame 3a protein of severe acute respiratory syndrome-associated coronavirus promotes membrane rearrangement and cell death. J. Virol. 84(2), 1097-1109.

Gao GF. 2018. From 'A'IV to 'Z'IKV: attacks from emerging and reemerging pathogens. Cell 172, 1157-1159.

Gao Q, Bao L, Mao H, Wang L, Xu K, Li Y, Zhu L, Wang N, Lv Z, Gao H, Ge X. 2020. Rapid development of an inactivated vaccine for SARS-CoV-2. Science eabc1932.

Geo-Vax 2020. Geovax and bravovax (wuhan, china) to collaborate on development of coronavirus vaccine. [cited $20203 \mathrm{March}$ ].

Guo G, Ye L, Pan K, Chen Y, Xing D, Yan K, Chen Z, Ding N, Li W, Huang H, Zhang L. 2020. New Insights of Emerging SARS-CoV-2: Epidemiology, Etiology, Clinical Features, Clinical Treatment, and Prevention. Front. Cell. Dev. Biol. 22(8), 410. 
Hemida MG, Abduallah MMB. 2020. The SARS-CoV-2 outbreak from a one health perspective. One Health 100127.

Hindson J. 2020. COVID-19: faecal-oral transmission? Nat. Reviews Gastroent. Hepatol. 11.

Hoffmann M, Kleine-Weber H, Schroeder S, Krüger N, Herrler T, Erichsen S, Schiergens TS, ACE2 and TMPRSS2 and is blocked by a clinically proven protease inhibitor. Cell 181(2), 271-280.e8.

Hoffmann M, Kleine-Weber H, Pöhlmann S. 2020b. A multibasic cleavage site in the spike protein of SARS-CoV-2 is essential for infection of human lung cells. Molecular Cell 78(4), 779-784.e5.

Holshue ML, DeBolt C, Lindquist S, Lofy KH, Wiesman J, Bruce H, Spitters C, Ericson K, Wilkerson S, Tural A, Diaz G. 2020. First case of 2019 novel coronavirus in the United States. N. Engl. J. Med. 382(10), 929-936.

Hoque MN, Istiaq A, Clement RA, Sultana M, Crandall KA, Siddiki AZ, Hossain MA. 2019. Metagenomic deep sequencing reveals association of microbiome signature with functional biases in bovine mastitis. Sci. Rep. 9, 13536.

Huang JM, Jan SS, Wei X, Wan Y, Ouyang S. 2020. Evidence of the Recombinant Origin and Ongoing Mutations in Severe Acute Respiratory Syndrome Coronavirus 2 (SARS-CoV2). bioRxiv. doi: https://doi.org/10.1101/2020.03.16.993816.

Hung IF, To KK, Lee CK, Lee KL, Chan K, Yan WW, Liu R, Watt CL, Chan WM, Lai KY, Koo CK. 2009. Convalescent plasma treatment reduced mortality in patients with severe pandemic influenza A (H1N1) 2009 virus infection. Clin. Infect. Dis. 52, 447-456. 
846

847

848

849

850

851

852

853

854

855

856

857

858

859

860

861

862

863

864

865

866

867

868

Inovio IP. 2020. Inovio selected by cepi to develop vaccine against new coronavirus inovio. [cited 202029 January].

Islam MR, Hoque MN, Rahman MS, Puspo JA, Akhter M, Akter S, Rubayet-Ul-Alam AS, Sultana M, Crandall KA, Hossain MA. 2020. Genome Wide Analysis of Severe Acute Respiratory Syndrome Coronavirus-2 Implicates World-Wide Circulatory Virus Strains Heterogeneity. Preprints 2020040137. doi: 10.20944/preprints202004.0137.v1.

Islam MT, Croll D, Gladieux P, Soanes DM, Persoons A. 2016. Emergence of wheat blast in Bangladesh was caused by a South American lineage of Magnaporthe oryzae. BMC Biol. 14, 84 .

Jackwood MW, Hall D, Handel A. 2012. Molecular evolution and emergence of avian gammacoronaviruses. Infect. Genet. Evol. 12(6), 1305-1311.

Jiang S, Hillyer C, Du L. 2020. Neutralizing antibodies against SARS-CoV-2 and other human coronaviruses. Trends Immunol. 41(5), 355-359.

Johnson and Johnson 2020. What You Need to Know About the Latest on the Coronavirusand a Potential Preventive Vaccine. https://www.jnj.com/latest-news/what-you-needto-know-about-coronavirus-and-a-potential-johnson-johnson-vaccine.

Kalita P, Padhi A, Zhang KY, Tripathi T. 2020. Design of a Peptide-Based Subunit Vaccine against Novel Coronavirus SARS-CoV-2. Preprints (www.preprints.org), doi:10.20944/preprints202003.0433.v1.

Kellner MJ, Koob JG, Gootenberg JS, Abudayyeh OO, Zhang F 2019. SHERLOCK: Nucleic Acid Detection with CRISPR Nucleases. Nat. Protoc. 14(10), 2986-3012.

Khailany RA, Safdar M, Ozaslan M. 2020. Genomic characterization of a novel SARS-CoV2. Gene Rep. 19, 100682. 
869

870

871

872

873

874

875

876

877

878

879

880

881

882

883

884

885

886

887

888

889

890

891

Khan S, Siddique R, Shereen MA, Ali A, Liu J, Bai Q, Bashir N, Xue M. 2020a. Emergence of a novel coronavirus (SARS-CoV-2), their biology and therapeutic options. J. Clinical Microbiol. 58(5).

Khan RJ, Jha RK, Amera GM, Jain M, Singh E, Pathak A, Singh RP, Muthukumaran J, Singh AK. 2020b. Targeting SARS-Cov-2: A systematic drug repurposing approach to identify promising inhibitors against 3C-like Proteinase and 2'-ORiboseMethyltransferase. J. Biomol. Struct. Dyn. 1 1-14.

Ko JH, Seok H, Cho SY, Ha YE, Baek JY, Kim SH, Kim YJ, Park JK, Chung CR, Kang ES, Cho D. 2018. Challenges of convalescent plasma infusion therapy in Middle East respiratory coronavirus infection: A single centre experience. Antivir. Ther. 23, 617622.

Kupferschmidt K. 2020. A cheap steroid is the first drug shown to reduce death in COVID19 patients. Science doi:10.1126/science.abd3683.

Lam TT, Shum MH, Zhu HC, Tong YG, Ni XB, Liao YS, Wei W, Cheung WY, Li WJ, Li LF, Leung GM. 2020. Identification of 2019-nCoV related coronaviruses in Malayan pangolins in southern China. Nature. https://doi.org/10.1038/s41586-020-2169-0.

Lane R. 2020. Sarah Gilbert: carving a path towards a COVID-19 vaccine. Lancet (London, England), 395(10232), 1247.

Lau SY, Wang P, Mok BW, Zhang AJ, Chu H, Lee AC, Deng S, Chen P, Chan KH, Song W, Chen Z. 2020. Attenuated SARS-CoV-2 variants with deletions at the S1/S2 junction. Emerg. Microbes Infect. 9(1), 837-842.

Li F, Li W, Farzan M, Harrison SC. 2005. Structure of SARS coronavirus spike receptorbinding domain complexed with receptor. Science 309, 1864-1868. 
892

893

894

895

896

897

898

899

900

901

902

903

904

905

906

907

908

909

910

911

912

913

914

Li G, He W, Zhu H, Bi Y, Wang R, Xing G, Zhang C, Zhou J, Yuen KY, Gao GF, Su S. 2018.

Origin, genetic diversity, and evolutionary dynamics of novel porcine circovirus 3 . Adv. Sci. 5(9), 1800275.

Li Y, Li S, Wang J, Liu G. 2019. CRISPR/Cas systems towards next-generation biosensing. Trends Biotechnol. 37, 730-743.

Li Z, Yi Y, Luo X, Xiong N, Liu Y, Li S, Sun R, Wang Y, Hu B, Chen W, Zhang Y. 2020a. Development and clinical application of a rapid IgM-IgG combined antibody test for SARS-CoV-2 infection diagnosis. J. Med. Virol. doi: 10.1002/jmv.25727.

Li H, Chen C, Hu F, Wang J, Zhao Q, Gale RP, Liang Y. 2020b. Impact of corticosteroid therapy on outcomes of persons with SARS-CoV-2, SARS-CoV, or MERS-CoV infection: a systematic review and meta-analysis. Leukemia 34, 1503-1511.

Lin X, Gong Z, Xiao Z, Xiong J, Fan B, Liu J. 2020. Novel coronavirus pneumonia outbreak in 2019: computed tomographic findings in two cases. Korean J. Radiol. 21(3), 365368.

Liu J, Cao R, Xu M, Wang X, Zhang H, Hu H. 2020. Hydroxychloroquine, a less toxic derivative of chloroquine, is effective in inhibiting SARSCoV-2 infection in vitro. Cell Discov. 6, 16.

Lu G, Hu Y, Wang Q, Qi J, Gao F, Li Y, Zhang Y, Zhang W, Yuan Y, Bao J, Zhang B. 2013. Molecular basis of binding between novel human coronavirus MERS-CoV and its receptor CD26. Nature 500, 227-231.

Lu R, Zhao X, Li J, Niu P, Yang B, Wu H, Wang W, Song H, Huang B, Zhu N, Bi Y. 2020. Genomic characterisation and epidemiology of 2019 novel coronavirus: implications for virus origins and receptor binding. The Lancet 395(10224), 565-574. 
915 Luke T, Wu H, Zhao J, Channappanavar R, Coleman CM, Jiao JA, Matsushita H, Liu Y, 916 Postnikova EN, Ork BL, Glenn G. 2016. Human polyclonal immunoglobulin G from 917 transchromosomic bovines inhibits MERS-CoV in vivo. Science Translatl. Med. $918 \quad \mathbf{8 ( 3 2 6 )}, 326$ ra21-326ra21.

919 Marra MA, Jones SJ, Astell CR, Holt RA, Brooks-Wilson A, Butterfield YS, Khattra J, Asano 920 JK, Barber SA, Chan SY, Cloutier A. 2003. The genome sequence of the SARSassociated coronavirus. Science 300(5624), 1399-1404.

Martinez MA. 2020. Compounds with therapeutic potential against novel respiratory 2019 coronavirus. Antimicrob. Agents Chemother. doi:10.1128/AAC.00399-20.

Mousavizadeh L, Ghasemi S. 2020. Genotype and phenotype of COVID-19: Their roles in pathogenesis.

J. Microbiol.

Immunol. Infect. https://doi.org/10.1016/j.jmii.2020.03.022.

Nishiura H, Linton NM, Akhmetzhanov AR. 2020. Initial cluster of novel coronavirus (2019928 $\mathrm{nCoV}$ ) infections in Wuhan, China is consistent with substantial human-to-human transmission. J. Clin. Med. 9(2), 488; https://doi.org/10.3390/jcm9020488.

Nuccetelli M, Pieri M, Grelli S, Ciotti M, Miano R, Andreoni M, Bernardini S. SARS-CoV2 infection serology: a useful tool to overcome lockdown?. Cell Death Discov. 6, 38 (2020).

Ou J, Zhou Z, Zhang J, Lan W, Zhao S, Wu J, Seto D, Zhang G, Zhang Q. 2020. RBD mutations from circulating SARS-CoV-2 strains enhance the structural stability and human ACE2 affinity of the spike protein. bioRxiv. doi: https://doi.org/10.1101/2020.03.15.991844. 
937 Pallesen J, Wang N, Corbett KS, Wrapp D, Kirchdoerfer RN, Turner HL, Cottrell CA, Becker

938

939

940

941

942

943

944

945

946

947

948

949

950

951

952

953

954

955

956

957

MM, Wang L, Shi W, Kong WP. 2017. Immunogenicity and structures of a rationally designed prefusion MERS-CoV spike antigen. Proc. Natl. Aca. Sci. 114(35), E7348E7357.

Phan T. 2020. Genetic diversity and evolution of SARS-CoV-2. Infect. Genet. Evol. 81, 104260.

Rahman MS, Hoque MN, Islam MR, Akter S, Rubayet-Ul-Alam AS, Siddique MA, Saha O, Rahaman MM, Sultana M, Hossain MA. 2020. Epitope-based chimeric peptide vaccine design against $\mathrm{S}, \mathrm{M}$ and $\mathrm{E}$ proteins of SARS-CoV-2 etiologic agent of global pandemic COVID-19: an in silico approach. bioRxiv. doi: https://doi.org/10.1101/2020.03.30.015164.

Regla-Nava JA, Nieto-Torres JL, Jimenez-Guardeño JM, Fernandez-Delgado R, Fett C, Castaño-Rodríguez C, Perlman S, Enjuanes L, DeDiego ML. 2015. Severe acute respiratory syndrome coronaviruses with mutations in the E protein are attenuated and promising vaccine candidates. J. Virol. 89, 3870-3887.

Reid AH, Fanning TG, Hultin JV, Taubenberger JK. 1999. Origin and evolution of the 1918 "Spanish" influenza virus hemagglutinin gene. Proc. Natl. Acad. Sci. USA 96, 16511656.

Reynard O, Nguyen XN, Alazard-Dany N, Barateau V, Cimarelli A, Volchkov VE. 2015. Identification of a new ribonucleoside inhibitor of Ebola virus replication. Viruses $7(12), 6233-6240$. 
958 Rota PA, Oberste MS, Monroe SS, Nix WA, Campagnoli R, Icenogle JP, Penaranda S, 959 Bankamp B, Maher K, Chen MH, Tong S. 2003. Characterization of a novel coronavirus associated with severe acute respiratory syndrome. Science 300(5624), 1394-1399.

961

962

963

964
Sanofi 2020. Sanofi joins forces with U.S. Department of Health and Human Services to advance a novel coronavirus vaccine. http://www.news.sanofi.us/2020-02-18-Sanofijoins-forces-with-U-S-Department-of-Health-and-Human-Services-to-advance-anovel-coronavirus-vaccine.

Sardar R, Satish D, Birla S, Gupta D. 2020. Comparative analyses of SAR-CoV2 genomes from different geographical locations and other coronavirus family genomes reveals unique features potentially consequential to host-virus interaction and pathogenesis. bioRxiv. doi: https://doi.org/10.1101/2020.03.21.001586.

Schoeman D, Fielding BC. 2019. Coronavirus envelope protein: current knowledge. Virol. J. 16, 69 .

Shang J, Wan Y, Luo C, Ye G, Geng Q, Auerbach A, Li F. 2020a. Cell entry mechanisms of SARS-CoV-2. Proc. Nat. Aca. Sci. 117(21), 11727-11734.

Shang W, Yang Y, Rao Y, Rao X. 2020b. The outbreak of SARS-CoV-2 pneumonia calls for viral vaccines. npj Vaccines 5(1), 1-3.

Shanmugaraj B. et al. 2020. Perspectives on monoclonal antibody therapy as potential therapeutic intervention for Coronavirus disease-19 (COVID-19). Asian Pac. J. Allergy Immunol. 38(1), 10-18.

Sheahan TP, Sims AC, Leist SR, Schäfer A, Won J, Brown AJ, Montgomery SA, Hogg A, Babusis D, Clarke MO, Spahn JE. 2020a. Comparative therapeutic efficacy of 
remdesivir and combination lopinavir, ritonavir, and interferon beta against MERSCoV. Nat. Commun. 11(1), 1-14.

982

983

984
Sheahan TP, Sims AC, Zhou S, Graham RL, Pruijssers AJ, Agostini ML, Leist SR, Schäfer A, Dinnon KH, Stevens LJ, Chappell JD. 2020b. An orally bioavailable broad-spectrum antiviral inhibits SARS-CoV-2 in human airway epithelial cell cultures and multiple coronaviruses in mice. Science Translatl. Med. eabb5883, doi: 10.1126/scitranslmed.abb5883.

hen Z, Xiao Y, Kang L, Ma W, Shi L, Zhang L, Zhou Z, Yang J, Zhong J, Yang D, Guo L. 2020. Genomic diversity of SARS-CoV-2 in Coronavirus Disease 2019 patients. Clinical Infect. Dis. ciaa203.

Shereen MA, Khan S, Kazmi A, Bashir N, Siddique R. 2020. COVID-19 infection: origin, transmission, and characteristics of human coronaviruses. J. Adv. Res. 24, 91-98.

Shi SQ, Peng JP, Li YC, Qin C, Liang GD, Xu L, Yang Y, Wang JL, Sun QH. 2006. The expression of membrane protein augments the specific responses induced by SARSCoV nucleocapsid DNA immunization. Mol. Immunol. 43, 1791-1798.

Song HD, Tu CC, Zhang GW, Wang SY, Zheng K, Lei LC, Chen QX, Gao YW, Zhou HQ, Xiang H, Zheng HJ. 2005. Cross-host evolution of severe acute respiratory syndrome coronavirus in palm civet and human. Proc. Natl. Acad. Sci. 102(7), 2430-2435.

Song W, Gui M, Wang X, Xiang Y. 2018. Cryo-EM structure of the SARS coronavirus spike glycoprotein in complex with its host cell receptor ACE2. PLoS Pathog. 14(8), e1007236.

Sui J, Li W, Roberts A, Matthews LJ, Murakami A, Vogel L, Wong SK, Subbarao K, Farzan M, Marasco WA. 2005. Evaluation of human monoclonal antibody 80R for 
immunoprophylaxis of severe acute respiratory syndrome by an animal study, epitope

1004 mapping, and analysis of spike variants. J. Virol. 79, 5900-5906.

1005

1006

1007

1008

1009

1010

1011

1012

1013

1014

1015

1016

1017

1018

1019

1020

1021

1022

1023

1024
Sun J, He WT, Wang L, Lai A, Ji X, Zhai X, Li G, Suchard MA, Tian J, Zhou J, Veit M. 2020. COVID-19: epidemiology, evolution, and cross-disciplinary perspectives. Trends Mol. Med. 26(5), 483-495.

Tang X, Wu C, Li X, Song Y, Yao X, Wu X, Duan Y, Zhang H, Wang Y, Qian Z, Cui J. 2020. On the origin and continuing evolution of SARS-CoV-2. Nat. Sci. Rev. nwaa036.

Tay MZ, Poh CM, Rénia L, MacAry PA, Ng LF. 2020. The trinity of COVID-19: immunity, inflammation and intervention. Nat. Rev. Immunol. 28, 1-2.

Ter Meulen J, Van Den Brink EN, Poon LL, Marissen WE, Leung CS, Cox F, Cheung CY, Bakker AQ, Bogaards JA, Van Deventer E, Preiser W. 2006. Human Monoclonal Antibody Combination against SARS Coronavirus: Synergy and Coverage of Escape Mutants. PLoS Med. 3(7), e237.

Tian X, Li C, Huang A, Xia S, Lu S, Shi Z, Lu L, Jiang S, Yang Z, Wu Y, Ying T. 2020. Potent binding of 2019 novel coronavirus spike protein by a SARS coronavirus-specific human monoclonal antibody. Emerg. Microbes Infect. 9(1), 382-385.

To KK, Tsang OT, Yip CC, Chan KH, Wu TC, Chan JM, Leung WS, Chik TS, Choi CY, Kandamby DH, Lung DC. 2020. Consistent detection of 2019 novel coronavirus in saliva. Clinical infectious diseases: an official publication of the Infectious Diseases Society of America. ciaa149.

oots M, Yoon JJ, Cox RM, Hart M, Sticher ZM, Makhsous N, Plesker R, Barrena AH, Reddy PG, Mitchell DG, Shean RC. 2019. Characterization of orally efficacious influenza drug 
with high resistance barrier in ferrets and human airway epithelia. Science Translatl.

1026

1027

1028

1029

1030

1031

1032

1033

1034

1035

1036

1037

1038

1039

1040

1041

1042

1043

1044

1045

1046
Med. 11(515).

Traggiai E, Becker S, Subbarao K, Kolesnikova L, Uematsu Y, Gismondo MR, Murphy BR, Rappuoli R, Lanzavecchia A. 2004. An efficient method to make human monoclonal antibodies from memory B cells: Potent neutralization of SARS coronavirus. Nat. Med. 10, 871-875.

u YF, Chien CS, Yarmishyn AA, Lin YY, Luo YH, Lin YT, Lai WY, Yang DM, Chou SJ, Yang YP, Wang ML. 2020. A review of SARS-CoV-2 and the ongoing clinical trials. Intl. J. Mol. Sci. 21(7), 2657.

Udugama B, Kadhiresan P, Kozlowski HN, Malekjahani A, Osborne M, Li VY, Chen H, Mubareka S, Gubbay JB, Chan WC. 2020. Diagnosing COVID-19: the disease and tools for detection. ACS Nano. 14(4), 3822-35.

Ul Qamar MT, Saleem S, Ashfaq UA, Bari A, Anwar F, Alqahtani S. 2019. Epitope-based peptide vaccine design and target site depiction against Middle East Respiratory Syndrome Coronavirus: an immune-informatics study. J. Translational Med. 17(1), 362. Valencia DN. 2020. Brief Review on COVID-19: The 2020 Pandemic Caused by SARS-CoV2. Cureus 12(3), e7386.

Walls AC, Park YJ, Tortorici MA, Wall A, McGuire AT, Veesler D. 2020. Structure, function, and antigenicity of the SARS-CoV-2 spike glycoprotein. Cell 181, 281-292.e6.

Wan Y, Shang J, Graham R, Baric RS, Li F. 2020. Receptor recognition by the novel coronavirus from Wuhan: an analysis based on decade-long structural studies of SARS coronavirus. J. Virol. 94(7). 
1047

1048

1049

1050

1051

1052

1053

1054

1055

1056

1057

1058

1059

1060

1061

1062

1063

1064

1065

1066

1067

1068

1069

Wang X, Xiong E, Tian T, Cheng M, Lin W, Wang H, Zhang G, Sun J, Zhou X. 2020a. Clustered Regularly Interspaced Short Palindromic Repeats/Cas9-Mediated Lateral Flow Nucleic Acid Assay. ACS Nano 14(2), 2497-2508.

Wang M, Cao R, Zhang L, Yang X, Liu J, Xu M, Shi Z, Hu Z, Zhong W, Xiao G. 2020 b. Remdesivir and chloroquine effectively inhibit the recently emerged novel coronavirus (2019-nCoV) in vitro. Cell Res. 269-271.

Wang C, Liu Z, Chen Z, Huang X, Xu M, He T, Zhang Z. 2020c. The establishment of reference sequence for SARS-CoV-2 and variation analysis. J. Med. Virol. PMID: 32167180.

Wang C, Li W, Drabek D. et al. 2020d. A human monoclonal antibody blocking SARS-CoV-2 infection. Nat. Commun. 11, 2251.

Wang N, Shang J, Jiang S, Du L. 2020e. Subunit vaccines against emerging pathogenic human coronaviruses. Front. Microbiol. 11, 298.

Wang N, Rosen O, Wang L, Turner HL, Stevens LJ, Corbett KS, Bowman CA, Pallesen J, Shi W, Zhang Y, Leung K. 2019. Structural Definition of a Neutralization-sensitive Epitope on the MERS-CoV S1-NTD. Cell Rep. 28(13), 3395-405.

Watanabe Y, Allen JD, Wrapp D, McLellan JS, Crispin M. 2020. Site-specific analysis of the SARS-CoV-2 glycan shield. Science eabb9983.

Wei Q, Ren Z. 2020. Disinfection measures for pneumonia foci infected by novel coronavirus in 2019. Chin. J. Disinfect. 37, 59-62.

WHO 2020. Statement on the second meeting of the International Health Regulations (2005) Emergency Committee regarding the outbreak of novel coronavirus (2019-nCoV). 2020. https://www.who.int/news-room/detail/30-01-2020-statement-on-the-second- 
1070

1071

1072

1073

1074

1075

1076

1077

1078

1079

1080

1081

1082

1083

1084

1085

1086

1087

1088

1089

1090

1091

1092 meeting-of-the-international-health-regulations-(2005)-emergency-committeeregarding-the-outbreak-of-novel-coronavirus-(2019-ncov). Accessed 1 Feb 2020. JS. 2020. Cryo-EM structure of the 2019-nCoV spike in the prefusion conformation. Science 367(6483), 1260-1263.

Wu A, Peng Y, Huang B, Ding X, Wang X, Niu P, Meng J, Zhu Z, Zhang Z, Wang J, Sheng J. 2020a. Genome composition and divergence of the novel coronavirus (2019-nCoV) originating in China. Cell Host Microbe. 27(3), 325-328.

Wu F, Zhao S, Yu B, Chen YM, Wang W, Song ZG, Hu Y, Tao ZW, Tian JH, Pei YY, Yuan ML. 2020b. A new coronavirus associated with human respiratory disease in China. Nature 579, 265-269.

Xiao K, Zhai J, Feng Y, Zhou N, Zhang X, Zou JJ, Li N, Guo Y, Li X, Shen X, Zhang Z. 2020. Isolation of SARS-CoV-2-related coronavirus from Malayan pangolins. Nature $7,1-4$.

Xinhua 2020. China fast-tracks novel coronavirus vaccine development Xinhua. [cited 20229 January].

Xu Y, Li X, Zhu B, Liang H, Fang C, Gong Y, Guo Q, Sun X, Zhao D, Shen J, Zhang H. 2020. Characteristics of pediatric SARS-CoV-2 infection and potential evidence for persistent fecal viral shedding. Nat. Med. 26, 502-505.

Yan R, Zhang Y, Li Y, Xia L, Guo Y, Zhou Q. 2020. Structural basis for the recognition of SARS-CoV-2 by full-length human ACE2. Science 367(6485), 1444-1448.

Yang D, Leibowitz JL. 2015. The structure and functions of coronavirus genomic 3' and 5' ends. Virus Res. 206, 120-133. 
1093

1094

1095

1096

1097

1098

1099

1100

1101

1102

1103

1104

1105

1106

1107

1108

1109

1110

1111

1112

1113

1114

Yin C. 2020. Genotyping coronavirus SARS-CoV-2: methods and implications. arXiv preprint arXiv 2003.10965.

Yuan M, Wu NC, Zhu X, Lee CC, So RT, Lv H, Mok CK, Wilson IA. 2020. A highly conserved cryptic epitope in the receptor-binding domains of SARS-CoV-2 and SARSCoV. Science eabb7269.

Zaki AM, Van Boheemen S, Bestebroer TM, Osterhaus AD, Fouchier RA. 2012. Isolation of a novel coronavirus from a man with pneumonia in Saudi Arabia. N. Engl. J. Med. 367(19), 1814-1820.

Zhang J, Zeng H, Gu J, Li H, Zheng L, Zou Q. 2020a. Progress and Prospects on Vaccine Development against SARS-CoV-2. Vaccines 8(2), 153.

Zhang L, Ren Q, Yang J, Lu Y, Zhang L, Gai Z. 2020b. Genome-wide variations of SARSCoV-2 infer evolution relationship and transmission route. medRxiv. doi: https://doi.org/10.1101/2020.04.27.20081349.

Zhang F, Jonathan Abudayyeh OO, Gootenberg JS. 2020c. A protocol for detection of COVID-19 using CRISPR diagnostics. https://www.broadinstitute.org/files/publications/special/COVID19.

Zhou H, Chen Y, Zhang S, Niu P, Qin K, Jia W, Huang B, Zhang S, Lan J, Zhang L, Tan W. 2019. Structural definition of a neutralization epitope on the N-terminal domain of MERS-CoV spike glycoprotein. Nat. Commun. 10, 3068.

Zhou P, Yang XL, Wang XG, Hu B, Zhang L, Zhang W, Si HR, Zhu Y, Li B, Huang CL, Chen HD. 2020a. A pneumonia outbreak associated with a new coronavirus of probable bat origin. Nature 579, 270-273. 
1115

1116

1117

1118

1119

1120

1121

1122

1123

1124

1125

1126
Zhou Y, Hou Y, Shen J, Huang Y, Martin W, Cheng F. 2020b. Network-based drug repurposing for novel coronavirus 2019-nCoV/SARS-CoV-2. Cell Dis. 6(1), 1-18.

Zhou Z, Post P, Chubet R, Holtz K, McPherson C, Petric M, Cox M. 2006. A recombinant baculovirus-expressed S glycoprotein vaccine elicits high titers of SARS-associated coronavirus (SARS-CoV) neutralizing antibodies in mice. Vaccine 24(17), 3624-3631.

Zhu N, Zhang D, Wang W, Li X, Yang B, Song J, Zhao X, Huang B, Shi W, Lu R, Niu P. 2020. A novel coronavirus from patients with pneumonia in China, 2019. N. Engl. J. Med. 382, 727-733. 


\section{Table $\mathbf{1}$ (on next page)}

Table 1

Genome-wide nucleotide mutations and amino-acid mutations and substitutions in SARS-

$\mathrm{CoV}-2$ strains. The number in the parentheses indicated the missense mutations. 
1 Genomic diversity and evolution, diagnosis, prevention, and therapeutics of the pandemic

2

3

4

5 Table 1: Genome-wide nucleotide mutations and amino-acid mutations and substitutions in

6 SARS-CoV-2 strains. The number in the parentheses indicated the missense mutations.

\begin{tabular}{|c|c|c|c|}
\hline Genome-site/position & $\begin{array}{c}\text { No. of amino-acid } \\
\text { replacements }\end{array}$ & $\begin{array}{c}\text { No. of nucleotide } \\
\text { mutations }\end{array}$ & References \\
\hline \multirow{2}{*}{ Polyprotein (nsp) } & 412 & \multirow{3}{*}{661} & Islam et al. (2020) \\
\hline & 757 & & Yin (2020) \\
\hline Leader sequence & 178 & & Yin $(2020)$ \\
\hline \multirow{7}{*}{ Spike (S) glycoprotein } & 120 & \multirow[t]{3}{*}{183} & Islam et al. (2020) \\
\hline & $14(8)$ & & Phan (2020) \\
\hline & 183 & & Yin (2020) \\
\hline & 7 & \multirow[t]{4}{*}{11} & Wang et al. (2020) \\
\hline & 13 & & Huang et al. (2020) \\
\hline & 18 & & Lu et al. (2020) \\
\hline & 6 & & Andersen et al. (2020) \\
\hline \multirow{5}{*}{ Membrane (M) protein } & 15 & \multirow[t]{3}{*}{34} & Islam et al. (2020) \\
\hline & $2(1)$ & & Phan (2020) \\
\hline & 33 & & Yin (2020) \\
\hline & & \multirow[t]{2}{*}{5} & Wang et al. (2020) \\
\hline & 2 & & Huang et al. (2020) \\
\hline \multirow{2}{*}{ Envelop (E) protein } & 11 & \multirow[t]{2}{*}{27} & Islam et al. (2020) \\
\hline & 2 & & Huang et al. (2020) \\
\hline \multirow{5}{*}{ Nucleocapsid $(\mathrm{N})$ protein } & 82 & \multirow[t]{2}{*}{148} & Islam et al. (2020) \\
\hline & $7(4)$ & & Phan (2020) \\
\hline & 6 & \multirow[t]{3}{*}{17} & Wang et al. (2020) \\
\hline & 5 & & Huang et al. (2020) \\
\hline & 222 & & Yin $(2020)$ \\
\hline \multicolumn{4}{|l|}{ Open-reading frames (ORFs) } \\
\hline ORF1a & 44 & & Huang et al. (2020) \\
\hline ORF1ab & $48(29)$ & & Phan (2020) \\
\hline ORF1ab & 8 & & Huang et al. (2020) \\
\hline ORF1ab & 6 & 43 & Wang et al. (2020) \\
\hline \multirow{4}{*}{ ORF3a } & 48 & \multirow[t]{3}{*}{92} & Islam et al. (2020) \\
\hline & 49 & & Yin $(2020)$ \\
\hline & 7 & & Huang et al. (2020) \\
\hline & 6 & 6 & Wang et al. (2020) \\
\hline ORF6 & 5 & 8 & Islam et al. (2020) \\
\hline \multirow{2}{*}{ ORF7a } & 22 & \multirow[t]{2}{*}{46} & Islam et al. (2020) \\
\hline & 2 & & Huang et al. (2020) \\
\hline ORF7b & 4 & 8 & Islam et al. (2020) \\
\hline \multirow{2}{*}{ ORF8 } & 16 & \multirow[t]{2}{*}{33} & Islam et al. (2020) \\
\hline & 8 & & Huang et al. (2020) \\
\hline & 34 & 34 & Wang et al. (2020) \\
\hline ORF10 & 10 & 17 & Islam et al. (2020) \\
\hline
\end{tabular}




\begin{tabular}{|lccl|} 
& 1 & & Huang et al. (2020) \\
\hline $5^{\prime}$-UTR & & 105 & $\begin{array}{l}\text { Islam et al. (2020) } \\
\text { Phan (2020) }\end{array}$ \\
\hline 3'-UTR & 3 & 158 & $\begin{array}{l}\text { Islam et al. (2020) } \\
\text { Phan (2020) }\end{array}$ \\
\hline 3'-to-5'exonuclease & 62 & & Yin et al. (2020) \\
\hline Spacer region & 6 & 6 & $\begin{array}{l}\text { Islam et al. (2020) } \\
\text { Phan (2020) }\end{array}$ \\
\hline
\end{tabular}

Here nsp, non-structural proteins; ORF, open-reading frames; UTR, untranslated region. 
Table 2 (on next page)

Table 2

Diagnostic protocols developed for SARS-CoV-2 
3 Genomic diversity and evolution, diagnosis, prevention, and therapeutics of the pandemic

Table 2: Diagnostic protocols developed for SARS-CoV-2

\begin{tabular}{|c|c|c|c|c|}
\hline $\begin{array}{c}\text { Type of clinical } \\
\text { sample }\end{array}$ & $\begin{array}{l}\text { Method/platform } \\
\text { (technology) }\end{array}$ & $\begin{array}{c}\text { Target } \\
\text { gene/Biomarker }\end{array}$ & $\begin{array}{c}\text { Who } \\
\text { developed }\end{array}$ & References \\
\hline $\begin{array}{l}\text { Upper and lower } \\
\text { respiratory } \\
\text { specimens* }\end{array}$ & Real-Time RTPCR & $N$ gene & U.S. CDC & $\begin{array}{l}\text { Anonymous } \\
(2020 \mathrm{a})\end{array}$ \\
\hline $\begin{array}{l}\text { Upper and lower } \\
\text { respiratory } \\
\text { specimens* }\end{array}$ & Real-Time RTPCR & $\begin{array}{l}\text { ORF } 1 a b \text { and } N \\
\text { gene }\end{array}$ & China, CDC & $\begin{array}{l}\text { Anonymous } \\
(2020 \mathrm{~b})\end{array}$ \\
\hline $\begin{array}{l}\text { Respiratory } \\
\text { specimens }\end{array}$ & Real-Time RTPCR & $\begin{array}{l}R d R p, E \text { and } N \\
\text { genes }\end{array}$ & $\begin{array}{l}\text { Multicountri } \\
\text { es: Germany, } \\
\text { The } \\
\text { Netherlands, } \\
\text { China, } \\
\text { France and } \\
\text { UK }\end{array}$ & $\begin{array}{l}\text { Corman et al. } \\
(2020)\end{array}$ \\
\hline $\begin{array}{l}\text { Respiratory } \\
\text { specimens }\end{array}$ & Real-Time RTPCR & $\begin{array}{l}R d R p / \mathrm{Hel}, S \text { and } N \\
\text { genes }\end{array}$ & $\begin{array}{l}\text { Hong Kong, } \\
\text { China }\end{array}$ & Chan et al. (2020a) \\
\hline Saliva & Real-Time RTPCR & $S$ gene & Hong Kong & To et al. (2020) \\
\hline $\begin{array}{l}\text { Human clinical } \\
\text { specimen }\end{array}$ & Real-Time RTPCR & $\begin{array}{l}\text { ORF } 1 b-n s p 14 \text { and } \\
N \text { genes }\end{array}$ & $\begin{array}{l}\text { Hong Kong } \\
\text { University }\end{array}$ & $\begin{array}{l}\text { Anonymous } \\
(2020 \mathrm{c})\end{array}$ \\
\hline Pharyngeal swab & Real-Time RTPCR & $N$ gene & $\begin{array}{l}\text { National } \\
\text { Institute of } \\
\text { Infectious } \\
\text { Diseases in } \\
\text { Japan }\end{array}$ & Nao et al. (2020) \\
\hline
\end{tabular}




\begin{tabular}{|lllll|}
\hline Serum & $\begin{array}{l}\text { CRISPR-Cas } \\
\text { (RPA) }\end{array}$ & $\begin{array}{l}\text { Nucleic acid } \\
\text { biomarker }\end{array}$ & China & $\begin{array}{l}\text { Wang et al. } \\
(2020 \mathrm{a})\end{array}$ \\
\hline $\begin{array}{l}\text { Nasopharyngeal } \\
\text { swabs }\end{array}$ & $\begin{array}{l}\text { CRISPR-Cas } \\
\text { (RTRPA) }\end{array}$ & $\begin{array}{l}\text { Nucleic acid } \\
\text { biomarker }\end{array}$ & USA & $\begin{array}{l}\text { Kellner et al. } \\
(2020)\end{array}$ \\
\hline $\begin{array}{l}\text { Synthetic COVID19 } \\
\text { virus RNA fragment }\end{array}$ & $\begin{array}{l}\text { CRISPR-based } \\
\text { SHERLOCK } \\
\text { (dipstick) }\end{array}$ & $\begin{array}{l}\text { ORFlab and } S \\
\text { genes }\end{array}$ & MIT, USA & $\begin{array}{l}\text { Zhang et al. } \\
\text { (2020c) }\end{array}$ \\
$\begin{array}{l}\text { Throat, nasal, } \\
\text { nasopharyngeal or } \\
\text { oropharyngeal } \\
\text { swabs }\end{array}$ & $\begin{array}{l}\text { ID NOWTM } \\
\text { COVID-19 }\end{array}$ & RdRp gene & Abbott & $\begin{array}{l}\text { https://bit.ly/3b0W } \\
8 b d\end{array}$ \\
\hline $\begin{array}{l}\text { Human finger } \\
\text { pricks or venous } \\
\text { whole blood, } \\
\text { serum, and plasma }\end{array}$ & Immunoassay & IgM/IgG & BioMedomic & https://bit.ly/2UXh \\
\hline $\begin{array}{l}\text { Human finger } \\
\text { pricks or venous } \\
\text { whole blood, } \\
\text { serum, and plasma }\end{array}$ & Immunoassay & IgM/IgG & sOF \\
\hline $\begin{array}{l}\text { Human finger } \\
\text { pricks or venous } \\
\text { whole blood, } \\
\text { serum, and plasma }\end{array}$ & Immunoassay & IgM/IgG & China & Li et al. (2020) \\
\hline
\end{tabular}
bronchoalveolar lavage, and nasopharyngeal wash/aspirate or nasal aspirate; RPA, recombinase polymerase amplification. 


\section{Figure 1}

Figure 1

Genome organization of (A) SARS-CoV-2, (B) SARS-CoV and (C) MERS-CoV. The genome of these three viruses comprises the $5^{\prime}$-untranslated region (5'-UTR), polyprotein with open reading frame (orf) $1 \mathrm{a} / \mathrm{b}$ (blue box) representing non-structural proteins (nsp) for replication, structural proteins including S glycoprotein (dark green box), envelop (E) (dark blue box), membrane (M) (orange box), and nucleocapsid (N) (yellow box) proteins, accessory proteins such as orf 3a/b (red boxes), 5 (black box), 6 (pink box), 7a/b, 8a/b, 9b and 10 (red boxes) , and the 3 -untranslated region (3'-UTR). The doted red lines (both in above and under) are the protein which show key differences among SARS-CoV-2, SARS-CoV and MERS-CoV. The nsps and orfs lengths are not drawn in scale (adapted from Islam et al., 2020; Shereen et al., 2020).

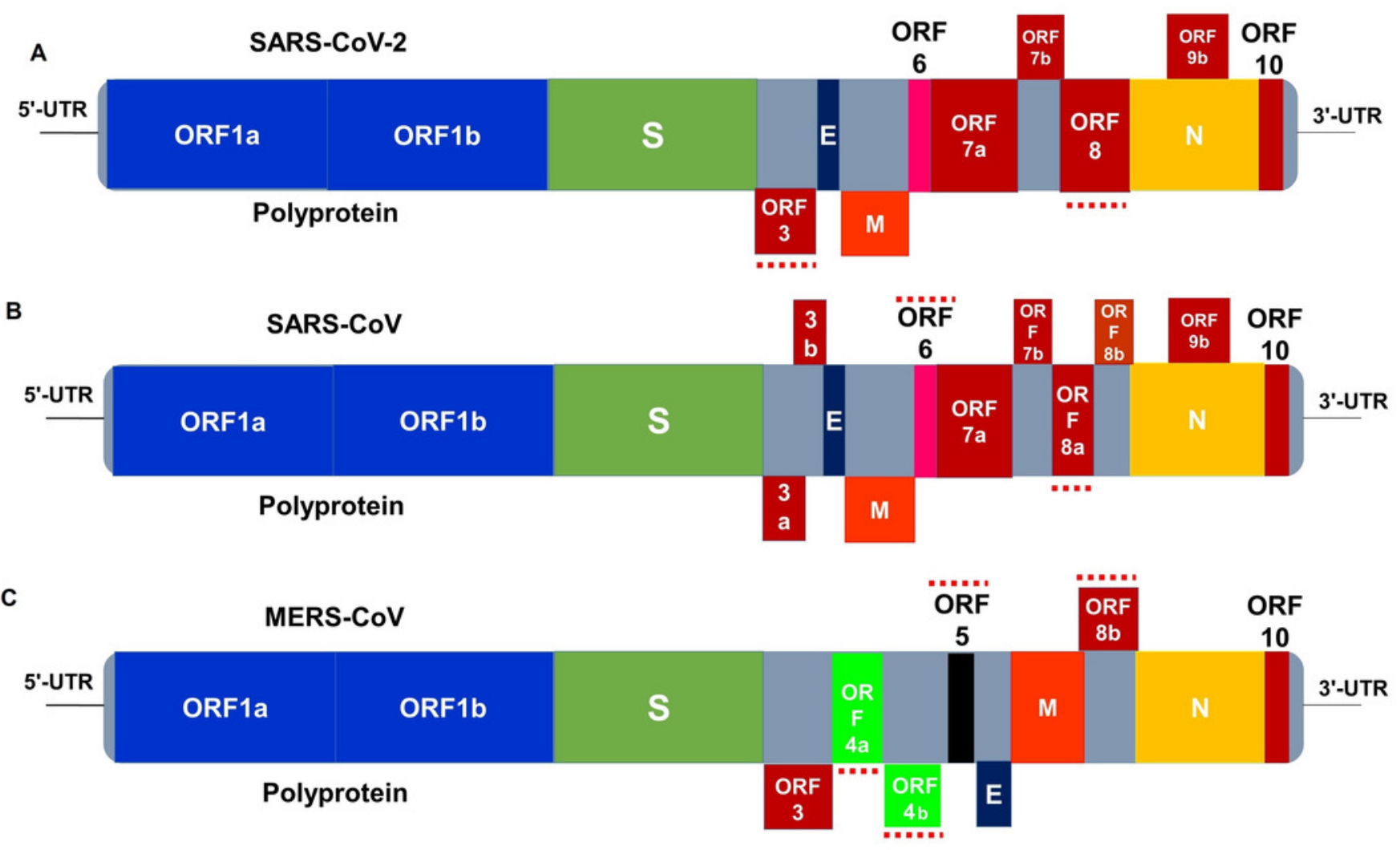




\section{Figure 2}

Figure 2

Phylogenetic tree of SARS-CoV-2. 200 complete genome sequences of SARS-CoV-2 retrieved from global initiative on sharing all influenza data (GISAID) (https://www.gisaid.org/) from different countries were used to build this tree. The sequences were aligned using MAFFT online server (Katoh et al., 2002), and a maximum likelihood tree was built with iTOL (interactive Tree Of Life). Each node represents a single strain which is found to be patient and/or sample specific, and not clustered according to geographical locations. Tree scale 0.01 , represents days before the time of lastly sampled genomes by scale*365. 


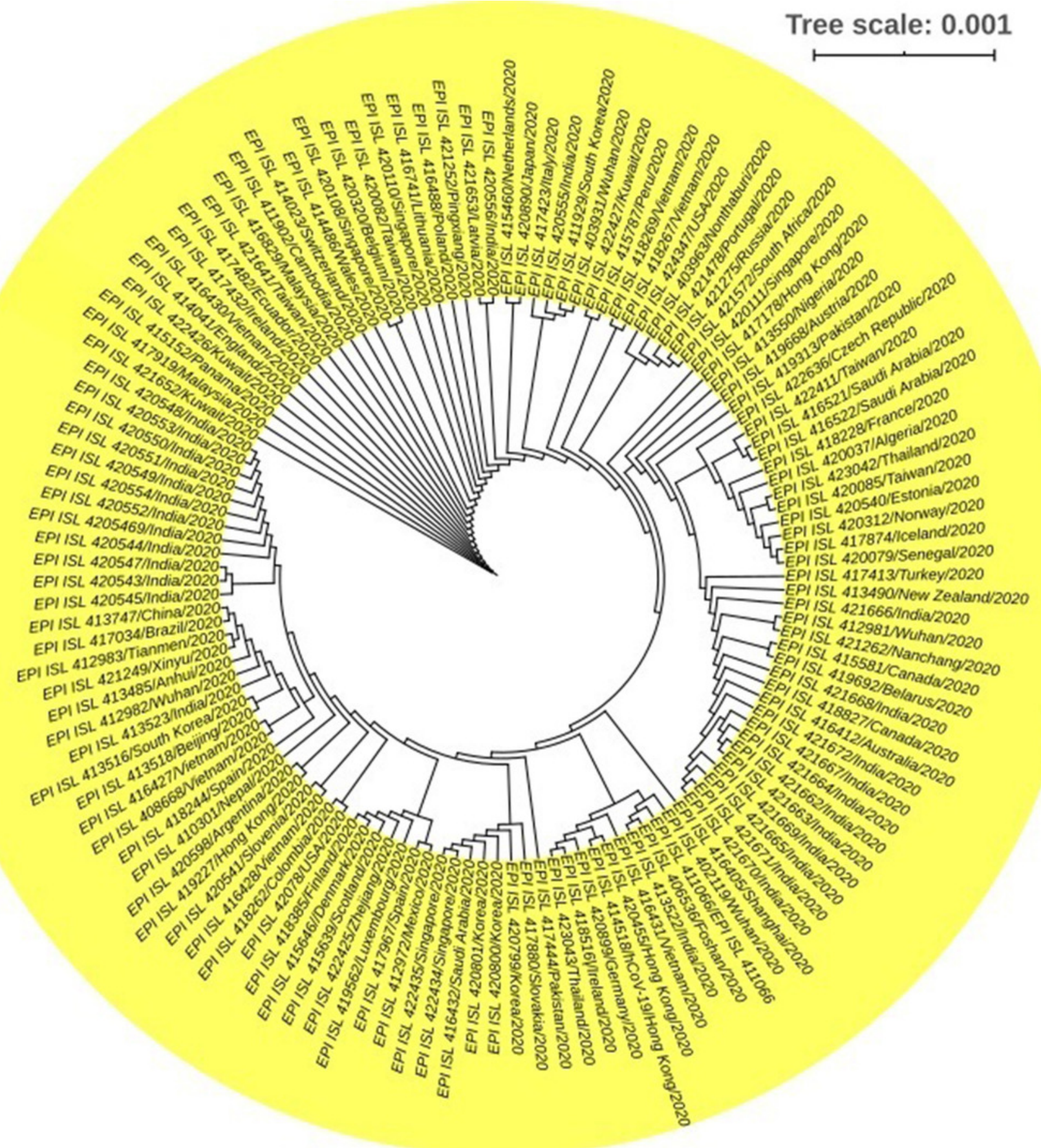




\section{Figure 3}

Figure 3

The dynamic curve showing daily increase in complete genome sequences of SARS-CoV-2 strain (s) from different patients across the globe, and being submitted to the reference databases. The data were collected from China National Center for Bioinformation 2019 Novel Coronavirus Resource (2019nCoVR) with available sequences from different countries (as on May 7, 2020).

The dynamic curve of sequences increase

$20 k$

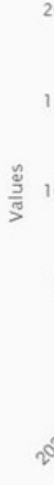

sis

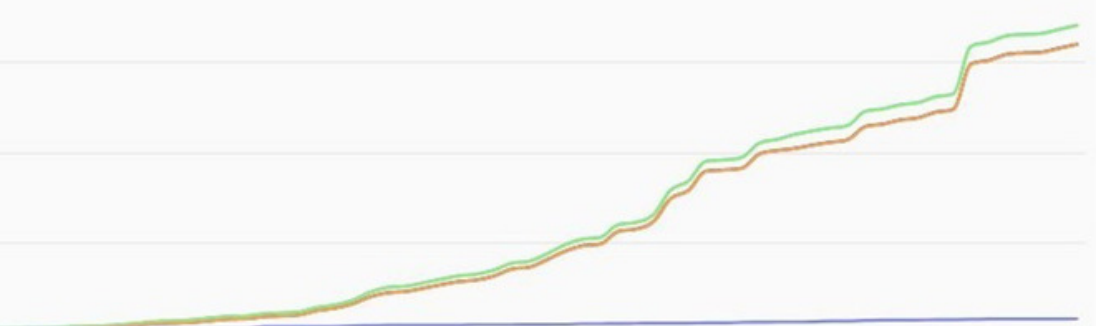
$2^{20} 5^{20}$ 